\title{
Mapping inland water bathymetry with Ground Penetrating Radar (GPR) on board Unmanned Aerial Systems (UASs)
}

Filippo Bandini ( $\square$ fban@env.dtu.dk)

Department of Environmental Engineering, Technical University of Denmark, 2800 Kgs. Lyngby, Denmark https://orcid.org/0000-0002-8470-2493

Lukas Kooij

Department of Environmental Engineering, Technical University of Denmark, 2800 Kgs. Lyngby, Denmark

Bjørn Karl Mortensen

Department of Environmental Engineering, Technical University of Denmark, 2800 Kgs. Lyngby, Denmark

Marie Boeskov Caspersen

Department of Environmental Engineering, Technical University of Denmark, 2800 Kgs. Lyngby, Denmark

Daniel Olesen

National Space Institute, Technical University of Denmark, 2800 Kgs. Lyngby, Denmark https://orcid.org/0000-0001-9922-0553

Peter Bauer-Gottwein

Department of Environmental Engineering, Technical University of Denmark, 2800 Kgs. Lyngby, Denmark https://orcid.org/0000-0002-9861-4240

\section{Research Article}

Keywords: UAS, Drone, Water Depth, Bathymetry, Sonar, GPR

Posted Date: September 9th, 2021

DOI: https://doi.org/10.21203/rs.3.rs-877656/v1

License: (c) (1) This work is licensed under a Creative Commons Attribution 4.0 International License. Read Full License

Version of Record: A version of this preprint was published at Journal of Hydrology on January 1st, 2023. See the published version at https://doi.org/10.1016/j.jhydrol.2022.128789. 


\section{Abstract}

Bathymetry of inland waterbodies is essential for river maintenance and flood risk management. Traditionally, in shallow depths bathymetry is retrieved by operators wading through the waterbody with Real Time Kinematic (RTK) Global Navigation Satellite System (GNSS), whilst in deeper depths it is retrieved with sonar instruments on manned or unmanned. In the past, researchers have documented the use of Ground Penetrating Radar (GPR) on boats (i.e. watercoupled GPR) for monitoring the bathymetry of frozen and non-frozen waterbodies. Furthermore, GPR has been used on helicopters for monitoring ice and snow thickness. However, deployment of GPR on board Unmanned Aerial Systems (UASs) in non-frozen inland water bodies with electric conductivity higher than $100 \mu \mathrm{S} / \mathrm{cm}$ (as is common in most inland waterbodies in non-polar regions) is unexplored. In this paper, we document the possibility to use drone-borne and water-coupled GPR in several cross-sections located in three different waterbodies (1 lake and 2 rivers) in Denmark. These waterbodies had different bed sediment materials and vegetation conditions, an electric conductivity varying from 200 to $340 \mu \mathrm{S} / \mathrm{cm}$ and depths up to 2.5 meters. Drone-borne GPR showed accuracy similar to water-coupled GPR when compared to RTK GNSS ground-truth measurements, with a Mean Absolute Error (MAE) of approx. $8 \mathrm{~cm}$. The only limitations of drone-borne GPR were i) worse minimum depth measurement capability (typically $0.8-1.1 \mathrm{~m}$ for drone-borne GPR, while $0.3-0.4$ metres for water-coupled GPR) ii) requirement to fly the GPR antenna at altitudes of approx. 0.5 meters above the water surface to avoid high spreading losses and strong surface clutter events hiding the signal. Finally, GPR measurements were benchmarked against traditional sonar measurements, showing that GPR measurements significantly outperform sonar measurements in waterbodies with medium or high density of aquatic vegetation.

\section{Introduction}

Bathymetric surveys are typically conducted to measure water depth and map the underwater features of a water body. Bathymetry of inland waterbodies plays a critical role in many hydrological and hydraulic problems and applications; indeed the hydrological regime of a lake is largely dependent on its bathymetry (Yao et al., 2018) and, similarly, the predictive skills of river hydrodynamic models depend on the accuracy of river cross-sections' shape (Grimaldi et al., 2018).

To optimize river maintenance and improve flood forecasting, bathymetry should be retrieved at regular time intervals with high spatial resolution. Indeed, the temporal variability of bathymetry, which is typically caused by processes such as sedimentation, erosion and human intervention (e.g. bottom dredging), can significantly change the frequency of overbank flooding under the same peak discharge conditions (Lane et al., 2007; Stover and Montgomery, 2001). Similarly, the high spatial variability of bathymetry along the river course may require continuous or very high-resolution mapping to accurately characterise the river morphology and geology (Diaconu et al., 2019; Merwade, 2009). To acquire bathymetric data, different techniques can be used, as described in the next sections.

\subsection{RTK GNSS surveys}

In shallower water, the conventional way of measuring river bathymetry is through cross-sectional surveys with RTK GNSS at certain locations along the river; however, these surveys typically require significant man-power and are time-consuming, thus the ratio cost/area covered is very high and investigation is typically limited to few cross-sections (Bangen et al., 2014; Feurer et al., 2008).

\subsection{Sonar}

In navigable rivers, river bathymetry is typically measured with single beam or multi-beam sonar on-board manned or unmanned vessels (Bio et al., 2020; Halmai et al., 2020; Leyland et al., 2017; Specht et al., 2020; Stateczny et al., 2019; Young et al., 2017). However, sonar systems have limitations in measuring very shallow depths due to surface clutter and multipath effects (Albright Blomberg et al., 2013); furthermore, the accuracy of sonar significantly degrades in vegetated rivers (Helminen et al., 2019), indeed the high level of reflection of sound waves from the vegetation can result in depth measurements within vegetation canopy (Sabol, 2002). Additionally, deployment of boats can be time-consuming in remote areas and is limited to navigable water. To alleviate the issues of sonar deployment in remote areas or non-navigable rivers, researchers (Alvarez et al., 2018; Bandini et al., 2018) and recently companies (e.g. UcGSSPH Engineering, Latvia, Thurn group (UK)) developed sonar systems tethered to an Unmanned Aerial System (UAS); however, the tethered sonar has to remain in contact with water throughout the survey, which complicates automatic pilot flights and reduces the possibility to perform beyond visual line of sight flights.

\subsection{Remote sensing methods}

To overcome the limitations of in-situ surveys, researchers have developed remote sensing methods to estimate water depth. These methods can be categorized into indirect methods, which typically determine the flow area or the mean water depth, and direct methods, which determine the full bathymetric shape. Indirect remote sensing methods are based, for instance, on estimating mean depth from satellite measurements of Water Surface Elevation (WSE) and modelled discharge (Leon et al., 2006), or estimating flow area from WSE and cross-section mean flow velocity (Moramarco et al., 2019). The focus of this paper is on direct methods, which are able to directly observe submerged topography and reconstruct the full cross-section shape. Direct methods to observe bathymetry include (i) through-water photogrammetry, ii) spectral methods, iii) bathymetric LiDAR.

Through-water photogrammetry is typically based on Structure-from-Motion (SfM) algorithms applied to UAS imagery and requires correction for the distinct refractive indices of water and air (Alvarez et al., 2018; Bagheri et al., 2015; Dietrich, 2016; Feurer et al., 2008; Lane et al., 2010; Tamminga et al., 2014; Westaway et al., 2001; Woodget et al., 2015).

Spectral methods are mostly based on the wavelength-dependent exponential attenuation of light in the water column and typically exploit the correlation between depth and reflectance, as according to Lyzenga (1978) or Stumpf et al. (2003). Spectral methods to estimate water depth of inland waterbodies have 
been applied to multispectral (or hyperspectral) or RGB images from i) satellites (Adler-Golden et al., 2005; Geyman and Maloof, 2019; Jagalingam et al., 2015; Lyons et al., 2011; Muzirafuti et al., 2020; Stumpf et al., 2003; Wei et al., 2020), ii) aircrafts (Carbonneau et al., 2006; Flener et al., 2012; Legleiter, 2012; Marcus et al., 2003; Winterbottom and Gilvear, 1997) and iii) UASs (Flener et al., 2013; Lejot et al., 2007; Rossi et al., 2020). To combine the advantages of the spectral approach, which performs better when the sediment is comparatively homogeneous (Legleiter et al., 2009; Lyzenga, 1981; Overstreet and Legleiter, 2017), and the photogrammetry approach, which performs better if the bottom is sufficiently textured to enable feature matching and ensures higher spatial resolution (Feurer et al., 2008), hybrid approaches have been demonstrated (Slocum et al., 2020; Starek and Giessel, 2017). However, both spectral and photogrammetry methods are limited to waterbodies with high water clarity and can deliver results only for depths lower than the Secchi depth. Thus, these passive remote sensing methods are typically applied to i) shallow coastal areas or ii) in rivers with sandy or gravel bottom and water depth less than 1-1.5 $\mathrm{m}$ (Brasington et al., 2003; Marcus et al., 2002; Winterbottom and Gilvear, 1997; Woodget et al., 2015) .

To overcome the limitations of passive sensors, active sensors such as bathymetric LiDAR systems (typically using green wavelength) have been used to monitor bathymetry of inland waterbodies from aircrafts (Bailly et al., 2010; Charlton et al., 2003; Hilldale and Raff, 2008; Kinzel et al., 2013, 2007; Lague and Feldmann, 2020; Pan et al., 2015) and recently also from satellite missions such as ICEsat-2 (Ma et al., 2020; Parrish et al., 2019). The cost, weight and size of bathymetric LiDAR systems challenge UAS deployment. However, in the last 5 years, green LiDAR systems, which comply with the payload weight restrictions of UAS, have entered the market, such as the i) laser profiler Riegl BDF-1 (Mandlburger et al., 2016), ii) the scanning LiDAR systems ASTRALiTe Edge Lidar (Kinzel and Legleiter, 2019), iii) the scanning LiDAR TDOT green (Amuse Oneself Inc, Japan). Furthermore, Chen et al. (2021) reported the design and performance of a photon-counting bathymetric Lidar based on a fiber-laser-pumped green laser. The main limitations of the commercial LiDAR systems are i) their cost (typically more than 150000 euros), ii) their penetration capability only up to 1-1.5 times the Secchi depth, iii) the uncertain performance for lowreflectivity bottom types and dense aquatic vegetation.

\subsection{GPR}

In frozen water bodies, Ground Penetrating Radar (GPR) outperforms other bathymetric remote sensing techniques because of the high penetration of GPR waves in ice and snow due to the low electric conductivity and low dielectric permittivity of these two media. In these applications, GPR can be deployed directly on the ice surface (Lapazaran et al., 2016; Liu et al., 2014, 2013; Moorman and Michel, 1997; Saintenoy et al., 2013; Shean and Marchant, 2010; Yoshikawa et al., 2006) or also from helicopters (Grab et al., 2018; Kovacs, 1979; Machguth et al., 2006; Merz et al., 2015; Rutishauser et al., 2016). However, in freshwater waterbodies, the high electric conductivity and high relative dielectric permittivity of water $(\approx 80)$, make GPR-based bathymetry monitoring of freshwater significantly more complex than monitoring of ice or snow. While the use of GPR deployed water-coupled from boats has been documented to successfully monitor bathymetry in lakes (Haeni, 1996; Kidmose et al., 2013, 2011; Lachhab et al., 2015; Sambuelli and Bava, 2012; Swain, 2018) and rivers (Sambuelli et al., 2009), air-launched GPR antennas are far less documented in the literature for bathymetric measurements of non-frozen waterbodies. Indeed, GPR penetration in deep water is dramatically reduced when the antenna is not water-coupled because of transmission, reflection and spreading losses (Delaney et al., 1990), and because the rough water surface severely degrades the coherence of the water surface transmission (Arcone and Calkins, 1990). Some tests have been performed with GPR antennas mounted on suspended cableways (Costa et al., 2006, 2000; Mason, 2004; Nobes et al., 2018; Spicer et al., 1997). However, at present, only one reference to helicopter-borne GPR monitoring of freshwater bathymetry is found (Melcher et al., 2002), although the characteristics of the sites (such as electric conductivity) were not given. Helicopter-borne deployment significantly reduces the survey time compared to water-coupled GPR; indeed, Melcher et al. (2002) reported that the helicopter could be flown at a low altitude (few meters above the surface) covering three sites located $100 \mathrm{~km}$ from each other within 60 minutes. GPR mounted on UASs would also increase survey speed compared to water-coupled GPRs and would allow for low altitude flights, which are significantly less dangerous with UASs than with manned helicopters.

In this paper, we show water-coupled and drone-borne GPR bathymetric measurements of freshwater bodies, with electric conductivity between 200 and 340 $\mu \mathrm{S} / \mathrm{cm}$. We also demonstrate the advantage of using GPR compared to sonar in highly vegetated shallow (less than 2.5 meters) waterbodies.

\section{Methodology}

In this chapter, we first summarize the main equations that describe the theoretical background of GPR detection of bathymetry, then we describe the survey methodology and the study areas.

\subsection{Theoretical Background-GPR detection of Bathymetry}

The GPR signal is significantly attenuated when travelling from air into the waterbody, through the waterbody, and finally reflected from the bottom of the waterbody. The total loss coefficient $a_{\text {total }}$ estimates the ratio between the emitted power $\left(P_{\text {emitted }}\right)$ and received power $\left(P_{\text {received }}\right)$, or the ratio between emitted electric field-strength ( $\left.E_{\text {emitted }}\right)$ and received electric field-strength $\left(E_{\text {received }}\right)$, as shown in Eq. ( 1 ). The total loss coefficient $a_{\text {total }}$ describes the losses involved in GPR signal propagation from the GPR transmitter to the receiver (through the waterbody) and can be calculated by adding up the individual losses, as shown in Eq. ( 2 ), in which we have i) the transmission loss $\left(a_{\text {trans }}\right)$ through the air-water interface; ii) the reflection loss $\left(a_{r}\right)$ from the bottom of the waterbody; iii) the propagation loss $\left(a_{p}\right)$ in water; iv) the spreading loss $\left(a_{\text {spread }}\right)$ in air and water. In $a_{\text {total }}$, we did not include losses such as i) radar system internal losses ii) temperature related losses. 


\begin{tabular}{|c|c|}
\hline$\alpha_{\text {total }}=10 \log _{10}\left(\frac{P_{\text {received }}}{P_{\text {emitted }}}\right)=20 \log _{10}\left(\frac{E_{\text {received }}}{E_{\text {emitted }}}\right)$ & (1) \\
\hline$\alpha_{\text {total }}=\left|\alpha_{\text {trans }}\right|+\left|\alpha_{r}\right|+\left|\alpha_{p}\right|+\left|\alpha_{\text {spread }}\right|$ & (2) \\
\hline
\end{tabular}

\subsubsection{Transmission Loss}

As the GPR wave propagates into water, it suffers a transmission loss ( $a_{\text {trans }}$ ) at the surface, which can be calculated with Eq. ( 3 ), as according to Jiang and Georgakopoulos (2011), and is equal to $8.9 \mathrm{~dB}$ for air-water transmission.

\begin{tabular}{|c|c|}
\hline$\alpha_{\text {trans }}=2 \cdot 10 \cdot \log _{10}\left(T^{2} \operatorname{Re}\left\{\frac{\eta_{\text {air }}}{\eta_{\text {water }}}\right\}\right)$ & (3) \\
\hline$T=\frac{2 \eta_{\text {water }}}{\eta_{\text {water }}+\eta_{\text {air }}}$ & (4) \\
\hline
\end{tabular}

In Eq. ( 3 ), multiplication by 2 is done because the wave needs to travel through the water surface twice. In the equation, $\eta$ is the intrinsic impedance (computed from the dielectric permittivity), specifically $\eta_{\text {air }}$ of air or $\eta_{\text {water }}$ of water, $R e\{$ indicates the real part of the complex number, $T$ is the transmission coefficient given by Eq. ( 4 ). In the formulation of the transmission loss coefficient, we do not consider that the transmission loss may be increased because of the water roughness induced by the downwash generated by a low-altitude flying UAS; however, in real-world scenario, this roughness would indeed increase surface cluttering (Rappaport et al., 2003), affect wave coherence (Arcone and Calkins, 1990) and increase the spreading of the GPR waves exiting water, thus decreasing the amount of radiation that the receiver acquires.

\subsubsection{Propagation Loss}

The attenuation of the GPR wave in water can be described through the coefficient $a_{\text {atten }}(\mathrm{Np} / \mathrm{m})$. Eq. ( 5 ), which is reported in Annan (2009), shows that the coefficient of attenuation $\left(a_{\text {atten }}\right)$ is a function of $\left.i\right)$ the absolute magnetic permeability of water $\left(\mu_{\text {water }}\right)$, ii) the real part of the absolute permittivity value of water $\left(\varepsilon_{\text {water }}\right)$, iii) the effective electric conductivity of water $\left(\sigma_{\text {water }}^{\mathrm{e}}\right)$. The variable $\varepsilon_{\text {water }}$ is obtained by multiplying the real component of the relative permittivity $\left(\varepsilon_{\text {water }}\right)$ by the permittivity of free space $\left(\varepsilon_{0}\right)$, similarly $\mu_{\text {water }}$ is obtained by multiplying the relative magnetic permeability of water $\left(\mu_{\text {water }} \approx 1\right)$ by magnetic permeability of free space $\left(\mu_{0}\right)$.

Effective conductivity ( $\sigma_{\text {water }}^{\mathrm{e}}$ ) can be computed through Eq. ( 6 ) (Cassidy, 2009), which contains the static electric conductivity of water ( $\left.\sigma_{\text {water }}\right)$, the imaginary component of the absolute permittivity of water $\left(\varepsilon^{\prime \prime}\right.$ water $)$, and the angular frequency of the GPR $(\omega)$. The variable $\varepsilon^{\prime \prime}$ water is obtained by multiplying the imaginary component of the relative permittivity by the electric permittivity of free space (Giannoukos et al., 2017). Different approaches exist to compute the GPR frequency (and thus the angular frequency) in the medium, such as using the centre frequency of the emitted wave (Lambot et al., 2004; Schwamborn et al., 2002), the entire bandwidth (Huisman et al., 2003), the frequency of the received wave or the dominant frequency expressed as $80 \%$ of the nominal centre frequency (Grimm et al., 2006; Pérez-Gracia et al., 2008). In this research, the last approach was adopted: the GPR frequency in water was considered equal to $80 \%$ of the nominal centre frequency and thus the angular frequency was computed accordingly.

As accordingly to Jiang and Georgakopoulos (2011), the propagation loss $\left(a_{p}\right)$ in $\mathrm{dB} / \mathrm{m}$ can be calculated with Eq. ( 7 ), in which the factor two is due to the double pass in water and $d$ is water depth. 


\begin{tabular}{|c|c|}
\hline$\alpha_{\text {atten }}=\sqrt{\frac{\mu_{\text {water }}}{\underline{\underline{\varepsilon}}_{\text {water }}}} \cdot \frac{\sigma_{\text {water }}^{e}}{2}$ & \\
\hline$\sigma_{\text {water }}^{e}=\sigma_{\text {water }}+\omega \underline{\varepsilon}_{\text {water }}^{\prime \prime}$ & \\
\hline$\alpha_{p}=2 \cdot 10 \cdot \log _{10}\left(e^{-2 \cdot \alpha_{\text {atten }} \cdot d}\right)$ & \\
\hline
\end{tabular}

\subsubsection{Reflection loss}

Reflection loss $\left(a_{r}\right)$ is calculated the same way as transmission losses, but by using the reflection coefficient (R), as shown in Eq. ( 8 ). The reflection loss is highly dependent on the impedance of the riverbed sediment material reflecting the wave, as shown in Eq. (9) (Annan, 2009; Reynolds, 1997).

\begin{tabular}{|c|c|}
\hline$\alpha_{r}=10 \log _{10}\left(|R|^{2}\right)$ & \\
\hline$R=\frac{\sqrt{\varepsilon_{\text {sediment }}}-\sqrt{\varepsilon_{\text {water }}}}{\sqrt{\varepsilon_{\text {water }}}+\sqrt{\varepsilon_{\text {sediment }}}}=\frac{\eta_{\text {water }}-\eta_{\text {sediment }}}{\eta_{\text {water }}+\eta_{\text {sediment }}}$ & \\
\hline
\end{tabular}

\subsubsection{Spreading loss}

Spreading loss, which is related to the flight height and water depth, can be calculated with Eq. ( 10 ), where $A_{\text {footprint,directWave }}$ is the footprint of the direct wave as received by the receiver, and $A_{\text {footprint,riverbed }}$ is the footprint at the river bottom. Computation of the GPR footprint is complicated and has been approximated by different authors with different equations (Pérez-Gracia et al., 2008). In this case, we applied Eq. ( 11 ) to compute the first Fresnel zone and estimate the radius at the water surface $\left(r_{\text {footprint,watersurface }}\right)$ from the wavelength in air $\left(\lambda_{\text {air }}\right)$ and the flight height $(h)$ above the water surface, as according to Leucci and Negri (2006) and Utsi (2004). This equation is chosen because Pérez-Gracia et al. (2008) proved with their experiments in water tanks that it can give a footprint approximation better than other common equations typically used to estimate the footprint such as the equations found in Leckebusch and Peikert (2001) or Conyers (2004), which provide a conservative estimation of the antenna's resolution capability and accurate estimation of the horizontal resolution (Pérez-Gracia et al., 2008). Experimental results determining the footprint when the GPR wave crosses multiple media (such as air and water) were not found; however, we here assume that the same equation Eq. (11) can be applied and thus the radius at the bottom of the water body ( $r_{\text {footprint,riverbed }}$ is computed with Eq. (12), which is basically a sum of the radius at the water surface after the GPR wave travels through air and the radius at the water bottom if the GPR was water-coupled. Thus, the second part of Eq. ( 12 ) contains also the wavelength in water $\left(\lambda_{\text {water }}\right)$ and water depth (d). With the assumption that the footprint is a perfect circle, the area $A_{\text {footprint,riverbed }}$ can be computed with Eq. (13). A critical factor in footprint calculation is the choice of the frequency from which to estimate the wavelength in air or water. Here, for computing $\lambda_{\text {air }}$ we use the centre frequency of the Gekko-80 ( $\approx 80 \mathrm{Mhz}$ ), whilst, for computing $\lambda_{\text {water, }}$ we use the dominant frequency in water, i.e. $80 \%$ of the centre frequency.

\begin{tabular}{|c|c|}
\hline$\alpha_{\text {spread }}=10 \log _{10}\left(\frac{A_{\text {footprint,directWave }}}{A_{\text {footprint,riverbed }}}\right)$ & (10) \\
\hline$r_{\text {footprint,water_surface }}=\sqrt{\left(h+\frac{\lambda_{\text {air }}}{4}\right)^{2}-h^{2}}$ & \\
\hline$r_{\text {footprint,riverbed }}=r_{\text {footprint,water_surface }}+\sqrt{\left(d+\frac{\lambda_{\text {water }}}{4}\right)^{2}-d^{2}}$ & \\
\hline$A_{\text {footprint,riverbed }}=\pi r_{\text {footprint,riverbed }}^{2}$ & \\
\hline
\end{tabular}




\subsubsection{Total loss}

The total loss can be computed with Eq. (2). An example of computation of total loss is shown in Appendix A, with a detailed calculation reported in the Supplementary Material. The computed total loss of $41.2 \mathrm{~dB}$ means that, out of a transmitted wave with electric field-strength of 1 , only an electric fieldstrength of approx. 0.01 can be detected in the radargram at the riverbed (i.e. rather small signal). These values do not include i) radar internal noise ii) temperature effects iii) effects of water surface roughness.

Figure 1 shows the different loss components in GPR transmission (through the water surface), propagation (through water), spreading (through both air and water), and reflection (from the bed of the waterbody).

In case the antenna was water-coupled, transmission loss would be approx. 0 and spreading loss would be only approx. $3.87 \mathrm{~dB}$, indeed, a significant amount of the spreading loss occurs in air. Thus, a water-coupled GPR antenna would exhibit a smaller total loss than an elevated antenna. Specifically, a watercoupled antenna would have a total loss of $28.85 \mathrm{~dB}$ instead of $41.2 \mathrm{~dB}$, resulting in a significant increase $(12.4 \mathrm{~dB})$ in return signal when the antenna is water-coupled. This is demonstrated in panels (b) and (c) in Fig. 1, in which we show the experimental result of lifting a handheld $80 \mathrm{MHz}$ GPR antenna from the water surface to 1 meter altitude in Fures $\emptyset$ lake. The radargram shows the return electric field-strength of the Gekko-80 antenna when water-coupled (around trace 20) and when elevated up to 1 meter (trace 430). The electric field-strength of the return wave corresponding to the lakebed (approximately 1 meter water depth) decreases from 5290 (water-coupled) to approx. 1190 bits when the antenna is elevated to 1 meter above the water surface: corresponding to $20 \cdot \log _{10}(5290 / 1190) \approx 12.9 \mathrm{~dB}$ loss when the antenna is elevated, thus comparable (given the uncertainty in spreading loss) to the theoretically computed value of $12.4 \mathrm{~dB}$. The total loss, consisting of transmission, spreading, propagation and reflection cannot be computed (e.g. by comparing water surface and bottom electric field-strength) from Fig. 1, because manufacturer hardware gains are applied to each trace with return times greater than approx. 30 ns, to improve the GPR wave penetration through water.

\subsection{GPR sensors}

In recent years, GPR manufactures have developed lightweight GPR units complying with the size and weight limitations of UAS and with frequencies (40-120 $\mathrm{MHz}$ ) suitable for bathymetry measurements of non-frozen waterbodies, as shown in Table 1.

Table 1

, comparison of different GPR systems suitable for drone-borne deployment that are suitable for bathymetry (also in non-frozen waterbodies).

\begin{tabular}{|c|c|c|c|c|c|}
\hline Producer & GPR system & $\begin{array}{l}\text { Center } \\
\text { Frequency }\end{array}$ & $\begin{array}{l}\text { Datalogger } \\
\text { unit }\end{array}$ & $\begin{array}{l}\text { Weight } \\
(\mathrm{kg})^{1}\end{array}$ & $\begin{array}{l}\text { Size }(\mathrm{cm} \times \mathrm{cm} \times \\
\mathrm{cm})\end{array}$ \\
\hline \multirow{4}{*}{$\begin{array}{l}\text { Radarteam AB (Sweden) } \\
\text { /UgCS (Latvia)/ Thurn } \\
\text { group (UK) }\end{array}$} & Model SE-40 & $\approx 40 \mathrm{MHz}$ & Cobra Plugln & $\approx 4.7$ & $200 \times 15 \times 21$ \\
\hline & & & (wireless system on board drone) & & \\
\hline & Model SE-70 & $\approx 70 \mathrm{MHz}$ & Same as SE-40 & $\approx 3.7$ & $139 \times 15 \times 21$ \\
\hline & Model SE-150 & $\approx 150 \mathrm{MHz}$ & Same as SE-40 & $\approx 3.2$ & $92 \times 22 \times 22$ \\
\hline $\begin{array}{l}\text { Malå (Guideline Geo AB- } \\
\text { Sweden) }\end{array}$ & $\begin{array}{l}\text { Malå } \\
\text { Geodrone } 80\end{array}$ & $\approx 80 \mathrm{MHz}$ & Unknown & $\approx 3.23$ & $58 \times 104 \times 24$ \\
\hline \multirow{3}{*}{$\begin{array}{l}\text { Geoscanners AB } \\
\text { (Sweden) }\end{array}$} & Gekko-120 & $\approx 120 \mathrm{MHz}$ & $\begin{array}{l}\text { RTS- } 1600 \text {, wireless system with also internal } \\
\text { datalogging }\end{array}$ & $\begin{array}{l}2.5+1 \mathrm{~kg} \\
\text { RTS } 1600\end{array}$ & $80 \times 12 \times 22.2$ \\
\hline & Gekko-80 & $\approx 80 \mathrm{MHz}$ & Same as Gekko-120 & $3.3+$ & $137 \times 12 \times 22.2$ \\
\hline & & & & 1 kg RTS1600 & \\
\hline
\end{tabular}

1 Including control unit/data-logger weight if that unit has to be onboard

The GPR units from Radarteam and Geoscanners use a signal sampling technique called Real-Time Sampling (RTS); RTS significantly improves signal-tonoise ratio compared to the alternative interleaved sequential sampling, whilst the Malå systems use High Dynamic Range (HDR), which is similar to RealTime Sampling. All the GPR antennas of Table 1 allow for 32-bit resolution, which results in a theoretical dynamic range of $190 \mathrm{~dB}$ and an effective dynamic range (after averaging, denoise, filtering) of approx. $150 \mathrm{~dB}$. The frequency of the antenna is a critical choice. Indeed, a lower frequency gives lower attenuation coefficient (thus lower propagation loss in water) and lower spreading loss; however, it results in a lower vertical resolution (typically one-fourth of the wavelength in water, thus approx. $10 \mathrm{~cm}$ for $80 \mathrm{MHz}$ ) and lower horizontal resolution.

\subsection{FIELD Instrumentation}

For this specific research, the GPR antenna Gekko-80 with RTS1600 data processing unit was deployed.

As sonar, the system Deeper Smart Sonar CHIRP+ (Deeper, UAB Lithuania) was deployed. This sonar records three different frequencies (each of which corresponding to a different scanning angle), specifically $100 \mathrm{kHz}\left(47^{\circ}\right), 240 \mathrm{kHz}\left(20^{\circ}\right)$ and $675 \mathrm{kHz}\left(7^{\circ}\right)$. The sonar has a maximum depth capability of 100 meters, and a minimum depth of $0.15 \mathrm{~m}(675 \mathrm{kHz}), 0.6 \mathrm{~m}(240 \mathrm{kHz})$ and $0.8 \mathrm{~m}(100 \mathrm{kHz})$. The sonar, when connected to a smartphone through the App Fish 
Deeper (Deeper, UAB Lithuania), displays the full waveform data in a colormap plot. However, from the logged data, the user can extract only one numeric water depth value per scan (corresponding to the value automatically estimated by the sonar software in real-time interpretation of the full waveform plot). The sonar can also be configured to send NMEA0183 messages, containing depth and position data from the in-built GNSS receiver, via WIFI to external devices.

In addition to GPR and sonar, the deployed system included i) a GNSS receiver ZED-F9P (U-blox, Switzerland) equipped with an Antcom (3G0XX16A4-XT-1-4Cert) multiband antenna, ii) a single-board computer BeagleBone Black (BeagleBoard.org). The single-board computer was programmed to i) log sonar data, ii) log raw GNSS observation and navigation messages and iii) send NMEA GPGGA sentences to the Gekko-80 processing unit.

The GPR system was tested both i) in water-coupled deployment on board an inflatable boat (made of non-conductive material) and ii) in drone-borne deployment on board the hexacopter DJI matrice 600 (DJI, China). The drone was equipped with a radar altimeter from UgCS (UgCS, SPH Engineering, Latvia). This radar altimeter enables flight at constant and low altitude in automatic flight missions planned with UgCS Ground Station Software.

Figure 2 shows the water-coupled and drone-borne deployment of the Gekko-80 system.

The inflatable boat was dragged along the cross-section from one side of the river to the other (or to a specific point in the lake case study). The UAS was flown over the same cross-section while keeping a constant low altitude with the GPR antenna approx. 0.5-0.6 m above the water surface.

An RTK GNSS rover station, consisting of a Trimble RTK GNSS R8s (Trimble Inc., USA) mounted on a carbon fibre pole, was deployed to retrieve i) ground-truth observations of the elevation of the bed of the waterbody ii) Water Surface Elevation (WSE), i.e. elevation of the water surface above reference geoid.

\subsection{Data processing}

\section{GNSS processing}

The GNSS data were processed in Post-Processed Kinematic (PPK) mode with the software RTKLIB Demo5 b34b from http://rtkexplorer.com/. This specific version of RTKLIB, which differs from the standard version available on http://www.rtklib.com/ (Takasu and Yasuda, 2009), enables processing of observations retrieved on the L2C GPS signal retrieved by the u-blox ZED-F9P.

The used GNSS reference station was either from a Continuously Operated Reference Station (CORS) provided by GPSnet.dk or a locally configured station (comprised of a NovAtel Flexpack6 receiver and a NovAtel GPS-703-GGG pinwheel triple frequency).

\section{GPR processing}

The GPR data were processed in the software GPRSoft ${ }^{\mathrm{TM}}$ (Geoscanners AB, Sweden), according to the following sequence of steps:

- The return from the water surface is identified to define the time-zero reference point. When the GPR is water-coupled, the water surface return is nearly a flat line. When the GPR is drone-borne, the water surface return may wiggle, because drone altitude above the water surface changes. However, since the GPR waves travel 10 times faster in air than in water and because of the vertical resolution (approx. $10 \mathrm{~cm}$ ) of the GPR, the effect of changing UAS altitude (typically only few $\mathrm{cm}$ ) is mostly negligible.

- A background removal filter was applied to the radargram to increase the signal-to-noise ratio by removing the banded events. The background removal is carried out by subtracting the moving average of the background noise from every trace in the GPR profile.

- The signal power of the existing GPR signal was amplified using gains, typically with logarithmic gain function.

- The bathymetry layer was extracted by using the layer picking tool provided by GPRSoft. The tool has several different methods, including a fully or partially "automated phase detection" method in which the software tries to follow a layer throughout the radargram based on the phase of a user-defined initial point.

- After the riverbed layer is identified, numeric values, such as trace number, return time and GNSS coordinates, are exported. Furthermore, a file containing NMEA GPGGA messages is exported. This file also contains information about the trace number at which each NMEA sentence (thus each UTC timestamp) was received.

- The coordinates in the riverbed layer file are corrected with the PPK position computed in RTKLIB. The PPK-computed positions are matched with the observations of the riverbed layer file by using the relationship between UTC timestamp and trace numbers.

- Return time of riverbed is converted into precise depth using the GPR wave speed in water ( $\left.\mathrm{v}_{\text {water }}\right)$ computed with Eq. ( 14 ), in which c is the speed in vacuum and $\varepsilon_{\text {water }}$ is the real component of relative permittivity of water. The variable $\varepsilon_{\text {water }}$ was estimated as a function of water temperature, with the relationship shown in Malmberg and Maryott (1956).

\begin{tabular}{|l|l|}
\hline$v_{\text {water }} \approx \frac{\mathrm{c}}{\sqrt{\varepsilon_{\text {water }}}}$ & \\
\hline
\end{tabular}

\section{Sonar processing}


The Deeper Smart Sonar CHIRP + provides NMEA0183 messages with depth and position from the in-built GNSS receiver. Since the in-built GNSS receiver is not very accurate, the UTC timestamps contained in the NMEA0183 are used to match the PPK-computed position so that the PPK-computed position can be used to accurately re-estimate sonar position.

\section{Conversion from depth into bathymetry}

Water depth observations, retrieved by sonar or GPR, are subtracted from WSE, retrieved by RTK GNSS, to compute bathymetry, thus elevation of the bed of the waterbody referenced to the chosen datum (in this research DVR90 geoid).

Lastly, the bathymetric measurements need to be assigned to a position along the cross-section reference line, which is defined by connecting the two reference points on the left and right streambanks. The cross-section line is thus divided into intervals of typically 0.2 meters: to each interval we assign the median of bathymetry measurements of each instrument (GPR, sonar or RTK GNSS) that are contained in that interval. Only observations with a maximum perpendicular distance from the observation to the cross-section line of typically 4 meters are included in the median. The search radius of 4 meters is chosen because the horizontal navigation accuracy of the UAS is not always optimal and an offset of few meters with respect to the cross-section line may occur.

\section{Error Statistics}

Error statistics, such as Mean Bias Error (MBE), Mean Absolute Error (MAE) and Root Mean Square Error (RMSE), were computed by comparing each RTK GNSS depth measurements to the median of depth measurements (sonar or GPR) contained in the same cross-section discretization interval, if observations were available in that interval. Statistics were computed on depth (not on bathymetry), e.g. a positive MBE for GPR means that the GPR overestimates depth compared to RTK GNSS.

\subsection{Study areas}

The study area consists of two rivers (Guden $\AA$ and its tributary Nørreå) and a lake (Furesø), all of which are located in Denmark, as shown in Fig. 3.

Twelve cross-sections in both Guden $\AA$, 2 in Nørreå, and 1 lake profile of approx. 70 meters in Fures $\varnothing$ were measured. Table 1 shows the characteristics for the sites, including water temperature and electric conductivity (measured with a commercial electric conductivity meter), bottom type and vegetation density, coordinates of markers located on left and right sides of the profiles and WSE (measured with RTK GNSS).

Fures $\varnothing$ presented a sandy bottom, while Guden Å presented a hard silty clay (but with several soft clay patches), and Nørreå had a soft clay with high water content. Vegetation was absent in Fures $\emptyset$. In Guden $\AA$, aquatic vegetation was present in all cross-sections but especially dense in some portions (typically the areas closer to the streambanks) of some cross-sections. The dominant plant species were Batrachium and Glyceria maxima, with the height of the vegetation typically 0.4-0.7 times the water depth. Similarly, in Nørreå, vegetation was sparser than in Guden Å but still present.

Water-coupled GPR was performed in all sites, while sonar and drone-borne GPR were performed in most sites but not all, depending on UAS availability. 
Table 2

, site characteristics. Table shows waterbody bottom type and vegetation characteristics, the static electric conductivity of water ( $\left.\sigma_{\text {water }}\right)$, water temperatur coordinates of the markers located on the left and right side of the cross-section (reference is ETRS89-UTM32 for all) and water surface elevation (WSE) in me DVR90 geoid. Surveying instrument: "GPR_DB" (drone-borne GPR), "S_100" for sonar 100 kHz, "S_240" for sonar $240 \mathrm{kHz}$, "S 675 " for sonar $675 \mathrm{kHz}$. "RTK GN GNSS) and "GPR_WC" (water-coupled GPR) were performed in all cross-sections.

\begin{tabular}{|c|c|c|c|c|c|c|c|c|}
\hline \multirow[t]{2}{*}{ Sites } & \multicolumn{2}{|c|}{ Coordinates of markers } & \multicolumn{2}{|c|}{$\begin{array}{l}\text { Qualitative } \\
\text { characteristics }\end{array}$} & \multicolumn{3}{|c|}{$\begin{array}{l}\text { Quantitative } \\
\text { characteristics }\end{array}$} & \multirow[t]{2}{*}{ Surveying instrument } \\
\hline & $\begin{array}{l}\text { Left } \\
\text { streambank } \\
\text { UTMy; } \\
\text { UTMx } \\
\text { [m] }\end{array}$ & $\begin{array}{l}\text { Right streambank } \\
\text { UTMy; } \\
\text { UTMx } \\
\text { [m] }\end{array}$ & $\begin{array}{l}\text { Bed } \\
\text { type }\end{array}$ & $\begin{array}{l}\text { Vegetation } \\
\text { density }\end{array}$ & $\begin{array}{l}\sigma_{\text {water }} \\
{[\mu \mathrm{S} / \mathrm{cm}]}\end{array}$ & $\begin{array}{l}\mathrm{T} \\
{\left[{ }^{\circ} \mathrm{C}\right]}\end{array}$ & $\begin{array}{l}\text { WSE } \\
\text { [m] }\end{array}$ & \\
\hline Fures $\emptyset$ & $\begin{array}{l}6187719.26 \\
715979.53\end{array}$ & $6187712.59 ; 715906.55$ & $\begin{array}{l}\text { Gravel } \\
\text { sand }\end{array}$ & $\begin{array}{l}\text { No } \\
\text { vegetation }\end{array}$ & 340 & 12 & 20.37 & RTK_GNSS;GPR_WC;GPR_DB;S_100;S_24 \\
\hline Guden_8370 & $\begin{array}{l}6230982.44 \\
541445.66\end{array}$ & $6230984.40 ; 541490.87$ & $\begin{array}{l}\text { silty } \\
\text { clay }\end{array}$ & $\begin{array}{l}\text { Dense } \\
\text { vegetation, } \\
\text { especially } \\
\text { near right } \\
\text { streambank }\end{array}$ & 243 & 14 & 17.85 & RTK_GNSS;GPR_WC;GPR_DB;S_240;S_67 \\
\hline Guden_8535 & $\begin{array}{l}6231153.68 \\
541476.94\end{array}$ & $6231127.74 ; 541522.25$ & $\begin{array}{l}\text { silty } \\
\text { clay }\end{array}$ & $\begin{array}{l}\text { Sparse } \\
\text { vegetation }\end{array}$ & 276 & 14 & 17.84 & RTK_GNSS;GPR_WC; \\
\hline Guden_8769 & $\begin{array}{l}6231360.11 ; \\
541528.21\end{array}$ & $6231356.49 ; 541580.44$ & $\begin{array}{l}\text { silty } \\
\text { clay }\end{array}$ & $\begin{array}{l}\text { Sparse } \\
\text { vegetation } \\
\text { with dense } \\
\text { patches }\end{array}$ & 267 & 14 & 17.76 & RTK_GNSS;GPR_WC;GPR_DB;S_100;S_24 \\
\hline Guden_8828 & $\begin{array}{l}6231415.31 ; \\
541530.51\end{array}$ & $6231417.90 ; 541582.91$ & $\begin{array}{l}\text { silty } \\
\text { clay, } \\
\text { sparse } \\
\text { rocks }\end{array}$ & $\begin{array}{l}\text { Sparse } \\
\text { vegetation }\end{array}$ & 277 & 14 & 17.73 & RTK_GNSS;GPR_WC;GPR_DB; \\
\hline Guden_8917 & $\begin{array}{l}6231493.51 ; \\
541507.46\end{array}$ & $6231504.11 ; 541550.52$ & $\begin{array}{l}\text { silty } \\
\text { clay }\end{array}$ & $\begin{array}{l}\text { Sparse } \\
\text { vegetation }\end{array}$ & 272 & 14 & 17.70 & RTK_GNSS;GPR_WC;GPR_DB; \\
\hline Guden_9021 & $\begin{array}{l}6231601.6 ; \\
541480.46\end{array}$ & $6231599.25 ; 541535.21$ & $\begin{array}{l}\text { silty } \\
\text { clay }\end{array}$ & $\begin{array}{l}\text { Dense } \\
\text { vegetation in } \\
\text { the centre }\end{array}$ & 274 & 14 & 17.63 & RTK_GNSS;GPR_WC;S_240;S_675; \\
\hline Guden_9158 & $\begin{array}{l}6231739.84 \\
541482.89\end{array}$ & $6231735.07 ; 541524.99$ & $\begin{array}{l}\text { silty } \\
\text { clay, } \\
\text { rocks } \\
\text { in the } \\
\text { middle }\end{array}$ & $\begin{array}{l}\text { Sparse } \\
\text { vegetation }\end{array}$ & 274 & 14 & 17.60 & RTK_GNSS;GPR_WC;GPR_DB;S_100;S_24 \\
\hline Guden_9261 & $\begin{array}{l}\text { 6231842.49; } \\
541515.12\end{array}$ & $6231824.999 ; 541560.56$ & $\begin{array}{l}\text { silty } \\
\text { clay }\end{array}$ & $\begin{array}{l}\text { Sparse } \\
\text { vegetation } \\
\text { with dense } \\
\text { patches }\end{array}$ & 283 & 14 & 17.58 & RTK_GNSS;GPR_WC;S_100;S_240;S_675; \\
\hline Guden_13770 & $\begin{array}{l}6235766.31 ; \\
540718.89\end{array}$ & $6235779.94 ; 540758.92$ & $\begin{array}{l}\text { silty } \\
\text { clay }\end{array}$ & $\begin{array}{l}\text { Dense } \\
\text { vegetation, } \\
\text { especially } \\
\text { near right } \\
\text { streambank }\end{array}$ & 292 & 14 & 15.54 & RTK_GNSS;GPR_WC;GPR_DB;S_100;S_24 \\
\hline Guden_13859 & $\begin{array}{l}6235836.33 ; \\
540675.24\end{array}$ & $\begin{array}{l}6235857 ; \\
540707.62\end{array}$ & $\begin{array}{l}\text { silty } \\
\text { clay }\end{array}$ & $\begin{array}{l}\text { Sparse } \\
\text { vegetation }\end{array}$ & 292 & 14 & 15.51 & RTK_GNSS;GPR_WC;GPR_DB;S_100;S_24 \\
\hline Guden_14796 & $\begin{array}{l}6236477.42 ; \\
540655.59\end{array}$ & $6236486.58 ; 540695.43$ & $\begin{array}{l}\text { silty } \\
\text { clay }\end{array}$ & $\begin{array}{l}\text { Sparse } \\
\text { vegetation }\end{array}$ & 198 & 10 & 15.6 & RTK_GNSS;GPR_WC;S_100;S_240;S_675; \\
\hline Guden_14963 & $\begin{array}{l}\text { 6236648.72; } \\
540631.64\end{array}$ & $6236630.05 ; 540670.30$ & $\begin{array}{l}\text { silty } \\
\text { clay }\end{array}$ & $\begin{array}{l}\text { Dense } \\
\text { vegetation, } \\
\text { especially } \\
\text { near } \\
\text { streambanks }\end{array}$ & 223 & 10 & 15.48 & RTK_GNSS;GPR_WC;S_100;S_240;S_675; \\
\hline Nørreå_43716 & $\begin{array}{l}6256123.08 \\
559420.38\end{array}$ & $\begin{array}{l}6256148.44 \\
559420.05\end{array}$ & $\begin{array}{l}\text { Soft } \\
\text { clay }\end{array}$ & $\begin{array}{l}\text { Sparse } \\
\text { vegetation }\end{array}$ & 291 & 10 & 0.43 & RTK_GNSS;GPR_WC;S_100;S_240;S_675; \\
\hline Nørreå_44013 & $\begin{array}{l}6256077.98 \\
559708.27\end{array}$ & $6256104.17 ; 559711.00$ & $\begin{array}{l}\text { Soft } \\
\text { clay }\end{array}$ & $\begin{array}{l}\text { Sparse } \\
\text { vegetation }\end{array}$ & 284 & 10 & 0.32 & RTK_GNSS;GPR_WC;S_100;S_240;S_675; \\
\hline
\end{tabular}




\section{Results}

In Fig. 4 and Fig. 5 we show the radargrams of four cross-sections ( 3 in Guden $\AA$ and 1 in Fures $\varnothing$ ), while Fig. 6 compares the bathymetry results of GPR, sonar (three frequencies) and ground-truth RTK GNSS. The radargrams and the bathymetry comparison plots of all the other cross-sections are reported in the Supplementary Material. In the radargrams, the blue line shows the identified water surface, while the red line highlights the GPR return from the waterbody bed. The red line is typically drawn by GPRsoft with "automated phase detection" method, while manual correction is performed by the user only in the small portions where automated detection fails (typically close to the streambanks). The radargrams show two significant differences when the antenna is droneborne (left panels) compared to when it is water-coupled (right panel): i) the electric field-strength of the return from the bed of the waterbody is weaker and ii) significantly higher noise level in the early portion of the radargram (visible as the white/black bands with strong electric field-strength that propagate from the water surface until approx. 70-100 ns). The noise affecting those earlier times is presumably caused by surface cluttering and multipath; indeed, this noise level was not detected when the handheld GPR was elevated (Fig. 1): the UAS carbon fibre structure is suspected to create multiple reflections of the GPR wave. Furthermore, compared to the handheld GPR case, we may assume that the roughness on the water surface induced by the UAS propellers can affect the water surface reflection loss, change wave coherence and increase surface clutter (Arcone and Calkins, 1990; Comite et al., 2017; Rappaport et al., 2003). The case of Fures $\varnothing$, which presents minor bed elevation changes along the cross-section (as visible in Fig. 6 ), is representative of the surface clutter issue: the noise completely covers the bottom return until the lake is at least $0.8 \mathrm{~m}$ deep when the GPR is drone-borne, whilst when the GPR is water-coupled also a depth as shallow as 0.4 meters can be detected.

However, in Guden Å cross-sections, also water-coupled GPR is unable to measure close to the stream banks (a. 1-2 meters horizontal distance from stream edges are unmeasured) for two main reasons: i) the GPR on-board the inflatable boat cannot be dragged up to the exact land-water edge ii) the large GPR footprint is not ideal for measuring the streambanks with steep slopes, causing larger errors in the measured depth close to the streambanks (e.g. due to strong reflections from the dry part) compared to deeper water. As for the Fures $\varnothing$ case, in Guden $\AA$ the drone-borne GPR has also a minimum depth that is sitedependant but is typically in the order of 1 meter (e.g. Guden_13859, Guden_13770 and Guden_9158 in Fig. 6) and thus higher than for the water-coupled case. The minimum detectable depth can vary depending on factors, such as i) slope of the waterbody bed and ii) distance from the streambanks. In terms of riverbed slope, typically higher slope improves the visibility of the returns from the riverbed in the radargram, especially after background noise removal, which typically removes flat horizontal bands such as the lines caused by surface clutter. In terms of distance from streambanks, portions of the waterbody that are the furthest away from the streambanks are easier to measure because the dry portion of the streambank creates returns that tend to hide the submerged portion. This is especially critical in light of the fact that low-frequency antennas, such as the Gekko-80, are unshielded and thus can detect radiation reflected from any direction.

The drone-borne GPR profile in Guden_9158 shows a deeper area in the centre that is not visible in water-coupled GPR and RTK GNSS. Among all case studies, this is the only example of significant discrepancy between water-coupled and drone-borne GPR measurements; however, because the significant strength of the signal of both the water-coupled and the drone-borne GPR radargram in that deep portion, it is assumed to be caused by the inaccuracy of UAS navigation: the UAS was flown approx. 3-4 meters horizontal distance from the cross-section line and thus the error in drone-borne GPR may be associated with riverbed heterogeneity along the river course.

In all the drone-borne GPR surveys, the GPR antenna was flown at a maximum height of approx. 0.5-0.6 m, because higher elevations showed higher noise level, weaker bottom reflection and stronger reflection from the dry portions of the streambanks, making identification of the waterbody bed more complex.

From Fig. 6, it is clear that the sonar measurements at $100 \mathrm{kHz}$ in Fures $\varnothing$ are faulty: this is most likely caused by the sediment type and especially by too shallow depth for the $100 \mathrm{kHz}$ frequency (despite a minimum depth of $0.8 \mathrm{~m}$ for the $100 \mathrm{kHz}$, the manufacturer suggests to use this frequency only for depths above 1.5 meters). On the other hand, the survey in Fures $\varnothing$ highlights that the minimum depth for $240 \mathrm{kHz}$ is approx. 0.6 meters.

Compared to sonar measurements, the main advantage of GPR is that the GPR can sense through dense aquatic vegetation. This is especially evident for the centre of the cross-sections in Guden_9021 and for the portions close to the streambanks in in Guden_13770 (Fig. 6 (b)), Guden_14963 and Guden_8370. Guden_8370, shown in Fig. 7, demonstrates that sonar bathymetric measurements show an elevation higher than RTK GNSS, caused by the sonar wave reflection from the vegetation canopy. Indeed, Guden_8370 was highly vegetated on the right side, as it was also shown in Fig. 2, in which the inflatable boat is standing on vegetation. Conversely, drone-borne and water-coupled GPR were not affected by vegetation and were able to penetrate through the submerged canopy.

The statistics comparing all the depth measurements are shown in Table 3; each statistic is computed by comparing the depth measurements of either sonar or GPR with RTK GNSS. Table 3 shows that water-coupled GPR shows slightly better statistics compared to drone-borne GPR in all cross-sections (apart from Guden_13859 and Guden_8828), however the main advantage of water-coupled GPR is that it can measure more shallow water and closer to the streambanks. Statistics are significantly better for GPR (water-coupled and drone-borne) than for any sonar frequency.

Among the sonar frequencies, the $100 \mathrm{kHz}$ shows the worst performance, whilst the $675 \mathrm{kHz}$ shows the best performance, apart from Guden_13770 (240 kHz is slightly better), Guden_14963 and Nørreå_43716. However, in Guden_14963 and Nørreå_43716 this is an artifact caused by the fact that the 675 kHz was unable (because of connectivity issues) to acquire fully continuous observations in the centre of the cross-section. This made the statistics not comparable: indeed, the sample size for the statistics computation is smaller for $675 \mathrm{kHz}$ compared to the other two frequencies.

The last row of Table 3 reports the average statistics among all sites; however, direct comparison of the averaged statistics of different instruments should be performed with caution as sonar or drone-borne GPR measurements are missing in some sites. The averaged statistics show that a MAE of approx. $8 \mathrm{~cm}$, a

Page $10 / 23$ 
MBE of approx. 0.02 and a RMSE of approx. $10 \mathrm{~cm}$ are achievable with drone-borne GPR, whilst similar statistics are achieved with water-coupled GPR (but on a larger number of sites). The cross-section in Nørreå_43716 (measured with water-coupled GPR and sonar) gave the worst statistics in terms of MAE and MBE for GPR, which may be caused by overestimation of depth in this cross-section that presented soft bottom.

Among the sonar frequencies, $675 \mathrm{kHz}$ and $240 \mathrm{kHz}$ show negative bias, which translates into underestimation of water depth (vegetation effect), whilst 100 $\mathrm{kHz}$ shows positive bias, which may indicate penetration below the bed of the waterbody.

Table 3

statistics comparing the depth measurements retrieved by the different instruments, benchmarked against RTK GNSS. MAE is Mean Absolute Error, MBE is Mean Bias Error, RMSE is Root Mean Square Error. Surveying instrument: "GPR_WC" (water-coupled GPR), "GPR_DB" (drone-borne GPR), "S_100" for sonar 100 kHz, "S_240" for sonar 240 kHz, "S_675" for sonar 675 kHz. The acronym n.a. stands for non-available. Last row reports the averaged statistics among all sites.

\begin{tabular}{|c|c|c|c|c|c|c|c|c|c|c|c|c|c|c|c|}
\hline \multirow[t]{2}{*}{ Site } & \multicolumn{5}{|l|}{ MAE } & \multicolumn{5}{|l|}{ MBE } & \multicolumn{5}{|c|}{ RMSE } \\
\hline & _WC & _DB & 100 & 240 & 675 & _WC & & 100 & 240 & 675 & _WC & & 100 & 240 & 675 \\
\hline Fures $\varnothing$ & 0.03 & 0.06 & 0.75 & 0.03 & 0.03 & -0.02 & 0.05 & 0.75 & 0.03 & 0.01 & 0.04 & 0.06 & 0.77 & 0.05 & 0.05 \\
\hline Guden_8370 & 0.05 & 0.06 & n.a. & 0.19 & 0.16 & -0.01 & -0.03 & n.a. & -0.09 & -0.09 & 0.07 & 0.08 & n.a. & 0.26 & 0.22 \\
\hline Guden_8769 & 0.09 & 0.06 & 0.30 & 0.15 & 0.12 & -0.02 & 0.03 & 0.20 & -0.07 & -0.11 & 0.12 & 0.08 & 0.52 & 0.20 & 0.18 \\
\hline Guden_8828 & 0.07 & 0.06 & n.a. & n.a. & n.a. & -0.01 & 0.04 & n.a. & n.a. & n.a. & 0.08 & 0.09 & n.a. & n.a. & n.a. \\
\hline Guden_8917 & 0.10 & 0.10 & n.a. & n.a. & n.a. & 0.07 & 0.08 & n.a. & n.a. & n.a. & 0.20 & 0.15 & n.a. & n.a. & n.a. \\
\hline Guden_9021 & 0.05 & n.a. & n.a. & 0.28 & 0.18 & 0.01 & n.a. & n.a. & -0.18 & -0.04 & 0.09 & n.a. & n.a. & 0.37 & 0.25 \\
\hline Guden_13859 & 0.12 & 0.04 & 0.18 & 0.16 & 0.11 & -0.05 & -0.02 & 0.00 & 0.08 & 0.02 & 0.18 & 0.05 & 0.28 & 0.38 & 0.15 \\
\hline Guden_14796 & 0.10 & n.a. & 0.16 & 0.13 & 0.08 & 0.04 & n.a. & -0.06 & 0.08 & 0.00 & 0.12 & n.a. & 0.21 & 0.19 & 0.12 \\
\hline Guden_14963 & 0.08 & n.a. & 0.36 & 0.20 & 0.31 & -0.08 & n.a. & 0.25 & -0.12 & -0.31 & 0.10 & n.a. & 0.58 & 0.24 & 0.38 \\
\hline Nørreå_43716 & 0.14 & n.a. & 0.21 & 0.12 & 0.19 & 0.12 & n.a. & 0.19 & 0.07 & -0.07 & 0.18 & n.a. & 0.32 & 0.15 & 0.30 \\
\hline Nørreå_44013 & 0.08 & n.a. & 0.20 & 0.12 & 0.06 & -0.06 & n.a. & 0.19 & 0.03 & 0.00 & 0.13 & n.a. & 0.36 & 0.18 & 0.08 \\
\hline AVERAGE & 0.08 & 0.08 & 0.28 & 0.15 & 0.13 & 0.00 & 0.02 & 0.18 & -0.02 & -0.05 & 0.13 & 0.10 & 0.40 & 0.22 & 0.19 \\
\hline
\end{tabular}

\section{Discussion}

We demonstrated that drone-borne GPR measurements are feasible in waterbodies with a conductivity up to $340 \mu \mathrm{S} / \mathrm{cm}$ and a depth up to 2.5 meters. GPR shows slightly worse statistics (depth overestimation) in a cross-section with soft bottom when compared to RTK GNSS. GPR was not tested in waterbodies with higher conductivity or higher water depths, thus the possibility of detecting drone-borne GPR measurements in those conditions remains unknown, especially because the propagation loss increases with electric conductivity and with depth.

Our research shows that GPR measurements give significantly better results than sonar in measuring bathymetry when compared to ground-truth. Groundtruth was taken with RTK GNSS, which has a typical nominal vertical accuracy of approx. $2-5 \mathrm{~cm}$; furthermore, when measuring soft riverbeds, the accuracy degrades because it is difficult to keep the bottom plate of the RTK GNSS pole exactly at the bed level instead of penetrating a few centimetres into the sediment. Furthermore, stones and local heterogeneities can complicate direct comparison between RTK GNSS and the footprint of GPR (or sonar). Additionally, Nobes et al. (2018) found that also suspended sediments can have an influence on the accuracy of bathymetric measurements. For these reasons, the achieved MAE of approx. $8 \mathrm{~cm}$ for GPR (both drone-borne and water-coupled) when compared to RTK GNSS is considered satisfactory.

RTK GNSS bathymetric measurements typically have a degree of subjectivity when the operator chooses the exact point where to measure (e.g. avoiding to measure on stones or taking measurements on stones), thus different surveys can result in slightly different results (unless measurements are taken at the exact same cross-section location). On the other hand, GPR surveys have always shown a high degree of repeatability, thus multiple profiles retrieved along the same cross-sections give nearly identical radargrams. However, a small degree of subjectivity is left to the user in choosing i) the return from the water surface and ii) the first point on the return from the bottom, especially in portions of the radargram where the "automated phase detection" method fails. Thus, different experienced users could extract slightly different depth observations (typically in the range of 5-10 $\mathrm{cm}$ ) from the same radargram, especially in the areas close to the streambanks. 
The sonar provides water depth measurements in real-time from automatic full waveform interpretation; however, if the user had the possibility to extract the full waveform as tabulated data, enhanced removal of vegetation and better interpretation of the bottom return from the full waveform data could improve results in post-processing.

Finally, integration of drone-borne GPR with techniques such as drone-borne topographic LiDAR (or photogrammetry) could be performed for estimating the elevation of both submerged (GPR) and dry (topographic LiDAR) portions of the cross-sections, while interpolation could be performed in the areas between dry and submerged parts.

\section{Conclusions}

This study assessed the performance of a water-coupled and drone-borne GPR for mapping bathymetry in inland water bodies. Significant signal losses (especially due to water surface reflection and spreading through air) affect elevated GPR antennas compared to water-coupled GPR: these losses were computed and subsequently demonstrated with an experiment in which a handheld antenna (elevated at approx. 1 meter above the water surface) was compared to a water-coupled GPR.

Field measurements of bathymetry were taken in three different sites (total surveyed cross-sections: 15 of which 1 in a lake) with drone-borne GPR, watercoupled GPR data, sonar and ground-truth RTK GNSS.

The following results were obtained:

- Both water-coupled and drone-borne GPR measurements (with GPR antenna flown at approx. 0.5 meters above the water surface) could detect the bed of the waterbodies.

- Two factors are required to effectively map bathymetry with drone-borne GPR; (i) a maximum GPR elevation above the water surface of approx. $0.5 \mathrm{~m}$ and (ii) a minimum water depth in the range 0.8-1.1 $\mathrm{m}$ depending on the inclination of the riverbed and distance to streambanks.

- Compared to drone-borne GPR, water-coupled GPR can measure shallower water depth (as low as $0.3-0.4$ metres), as the noise caused by surface clutter on the early portions of the radargram does not occur when the GPR antenna is water-coupled.

- Both water-coupled and drone-borne GPR provided accurate results with an average MAE of approx. $8 \mathrm{~cm}$ (thus similar to the vertical resolution of the GPR at this frequency) compared to in situ RTK GNSS. No significant bias was identified in GPR measurements compared to RTK GNSS.

- The applicability of the GPR bathymetry monitoring solution was not limited by the conditions at the chosen survey sites in relation to aquatic vegetation, water electric conductivity (tested up to $340 \mu \mathrm{S} / \mathrm{cm}$ ), or maximum water depth (tested up to $2.5 \mathrm{~m}$ ). GPR was applicable also in waterbodies with soft clay bed, but resulted in slightly worse statistics when compared to ground-truth.

- The sonar provided unreliable (biased) results in vegetated water bodies, but performed well in non-vegetated water bodies when operated at $240 \mathrm{kHz}$ and $675 \mathrm{kHz}$.

\section{Declarations}

\section{Funding}

This work was supported by the project "Mapping of depth and sediment layer thickness of freshwater bodies with Ground Penetrating Radar (GPR) onboard drones" within the VIS ("Europas grønne region - innovative løsninger på vandområdet") framework funded by the European Regional Development Fund and the projects "Riverscapes" (file number 7048-00001B) and "ChinaWaterSense" (file number 8087-00002B) funded by the Innovation Fund Denmark (Innovationsfonden).

\section{Acknowledgements}

We thank Niels Henrik Broge and Mark Lyon from Geopartner Inspections A/S for collaboration and co-financing in the VIS project.

We thank WSP engineering consulting firm for sharing the ground-truth RTK GNSS observations. In-situ observations were acquired independently by a professional operator from WSP to perform an independent accuracy validation test of the bathymetric observations.

Competing interests: The authors declare no competing interests.

\section{References}

Adler-Golden, S.M., Acharya, P.K., Berk, A., Matthew, M.W., Gorodetzky, D., 2005. Remote bathymetry of the littoral zone from AVIRIS, LASH, and QuickBird imagery. IEEE Trans. Geosci. Remote Sens. https://doi.org/10.1109/TGRS.2004.841246

Albright Blomberg, A.E., Austeng, A., Hansen, R.E., Synnes, S.A.V., 2013. Improving sonar performance in shallow water using adaptive beamforming. IEEE J. Ocean. Eng. https://doi.org/10.1109/JOE.2012.2226643

Alvarez, L. V., Moreno, H.A., Segales, A.R., Pham, T.G., Pillar-Little, E.A., Chilson, P.B., 2018. Merging Unmanned Aerial Systems (UAS) Imagery and echo soundings with an adaptive sampling technique for bathymetric surveys. Remote Sens. https://doi.org/10.3390/rs10091362 
Andryieuski, A., Kuznetsova, S.M., Zhukovsky, S. V., Kivshar, Y.S., Lavrinenko, A. V., 2015. Water: Promising Opportunities for Tunable All-dielectric Electromagnetic Metamaterials. Sci. Rep. https://doi.org/10.1038/srep13535

Annan, P., 2009. Electromagnetic principles of ground penetrating radar, in: Ground Penetrating Radar. https://doi.org/10.1016/B978-0-444-53348-7.00001-6 Arcone, S.A., Calkins, D.J., 1990. Radar surveying of the bottom surface of ice covers. Can. J. Remote Sens. https://doi.org/10.1080/07038992.1990.11487604

Bagheri, O., Ghodsian, M., Saadatseresht, M., 2015. Reach scale application of UAV + SfM method in shallow rivers hyperspatial bathymetry, in: International Archives of the Photogrammetry, Remote Sensing and Spatial Information Sciences - ISPRS Archives. pp. 77-81. https://doi.org/10.5194/isprsarchives-XL-1W5-77-2015

Bailly, J.S., le Coarer, Y., Languille, P., Stigermark, C.J., Allouis, T., 2010. Geostatistical estimations of bathymetric LiDAR errors on rivers. Earth Surf. Process. Landforms 35, 1199-1210. https://doi.org/10.1002/esp.1991

Bandini, F., Olesen, D., Jakobsen, J., Kittel, C.M.M., Wang, S., Garcia, M., Bauer-Gottwein, P., 2018. Technical note: Bathymetry observations of inland water bodies using a tethered single-beam sonar controlled by an unmanned aerial vehicle. Hydrol. Earth Syst. Sci. 22, 4165-4181. https://doi.org/10.5194/hess-22$4165-2018$

Bangen, S.G., Wheaton, J.M., Bouwes, N., Bouwes, B., Jordan, C., 2014. A methodological intercomparison of topographic survey techniques for characterizing wadeable streams and rivers. Geomorphology 206, 343-361. https://doi.org/10.1016/j.geomorph.2013.10.010

Bio, A., Gonçalves, J.A., Magalhães, A., Pinheiro, J., Bastos, L., 2020. Combining Low-Cost Sonar and High-Precision Global Navigation Satellite System for Shallow Water Bathymetry. Estuaries and Coasts. https://doi.org/10.1007/s12237-020-00703-6

Brasington, J., Langham, J., Rumsby, B., 2003. Methodological sensitivity of morphometric estimates of coarse fluvial sediment transport. Geomorphology. https://doi.org/10.1016/S0169-555X(02)00320-3

Carbonneau, P.E., Lane, S.N., Bergeron, N., 2006. Feature based image processing methods applied to bathymetric measurements from airborne remote sensing in fluvial environments. Earth Surf. Process. Landforms 31, 1413-1423. https://doi.org/10.1002/esp.1341

Cassidy, N., 2009. Electrical and magnetic properties of rocks, soils and fluids, in: Ground Penetrating Radar. https://doi.org/10.1016/B978-0-444-533487.00002-8

Charlton, M.E., Large, A.R.G., Fuller, I.C., 2003. Application of airborne lidar in river environments: The River Coquet, Northumberland, UK. Earth Surf. Process. Landforms 28, 299-306. https://doi.org/10.1002/esp.482

Chen, X., Kong, W., Chen, T., Huang, G., Shu, R., 2021. Fiber-laser-pumped green laser for photon-counting bathymetric Lidar on UAV platform. https://doi.org/10.1117/12.2586528

Comite, D., Ahmad, F., Dogaru, T., Amin, M.G., 2017. Coherence factor for rough surface clutter mitigation in forward-looking GPR, in: 2017 IEEE Radar Conference, RadarConf 2017. https://doi.org/10.1109/RADAR.2017.7944500

Conyers, L.B., 2004. Ground-penetrating radar for archaeology. AltaMira Press, Walnut Creek, California ISBN 0-759-10773-4. Archaeol. Prospect. https://doi.org/10.1002/arp.288

Costa, J.E., Cheng, R.T., Haeni, F.P., Melcher, N., Spicer, K.R., Hayes, E., Plant, W., Hayes, K., Teague, C., Barrick, D., 2006. Use of radars to monitor stream discharge by noncontact methods. Water Resour. Res. 42. https://doi.org/10.1029/2005WR004430

Costa, J.E., Spicer, K.R., Cheng, R.T., Haeni, F.P., Melcher, N.B., Thurman, E.M., Plant, W.J., Keller, W.C., 2000. Measuring stream discharge by non-contact methods: A proof-of-concept experiment. Geophys. Res. Lett. 27, 553-556. https://doi.org/10.1029/1999GL006087

Delaney, A.J., Arcone, S.A., Chacho, E.F., 1990. Winter short-pulse radar studies on the Tanana River, Alaska. Arctic. https://doi.org/10.14430/arctic1618

Diaconu, D.C., Bretcan, P., Peptenatu, D., Tanislav, D., Mailat, E., 2019. The importance of the number of points, transect location and interpolation techniques in the analysis of bathymetric measurements. J. Hydrol. https://doi.org/10.1016/j.jhydrol.2018.12.070

Dietrich, J.T., 2016. Bathymetric Structure from Motion: Extracting shallow stream bathymetry from multi-view stereo photogrammetry. Earth Surf. Process. Landforms 42, 355-364. https://doi.org/10.1002/esp.4060

Feurer, D., Bailly, J.-S., Puech, C., Le Coarer, Y., Viau, A.A., 2008. Very-high-resolution mapping of river-immersed topography by remote sensing. Prog. Phys. Geogr. 32, 403-419. https://doi.org/10.1177/0309133308096030

Flener, C., Lotsari, E., Alho, P., Käyhkö, J., 2012. Comparison of empirical and theoretical remote sensing based bathymetry models in river environments. River Res. Appl. https://doi.org/10.1002/rra.1441 
Flener, C., Vaaja, M., Jaakkola, A., Krooks, A., Kaartinen, H., Kukko, A., Kasvi, E., Hyyppä, H., Hyyppä, J., Alho, P., 2013. Seamless mapping of river channels at high resolution using mobile liDAR and UAV-photography. Remote Sens. 5, 6382-6407. https://doi.org/10.3390/rs5126382

Geyman, E.C., Maloof, A.C., 2019. A Simple Method for Extracting Water Depth From Multispectral Satellite Imagery in Regions of Variable Bottom Type. Earth Sp. Sci. https://doi.org/10.1029/2018EA000539

Giannoukos, G., Min, M., Rang, T., 2017. Relative complex permittivity and its dependence on frequency. World J. Eng. https://doi.org/10.1108/WJE-01-20170007

Grab, M., Bauder, A., Ammann, F., Langhammer, L., Hellmann, S., Church, G.J., Schmid, L., Rabenstein, L., Maurer, H.R., 2018. Ice volume estimates of Swiss glaciers using helicopter-borne GPR - An example from the Glacier de la Plaine Morte, in: 2018 17th International Conference on Ground Penetrating Radar, GPR 2018. https://doi.org/10.1109/ICGPR.2018.8441613

Grimaldi, S., Li, Y., Walker, J.P., Pauwels, V.R.N., 2018. Effective Representation of River Geometry in Hydraulic Flood Forecast Models. Water Resour. Res. https://doi.org/10.1002/2017WR021765

Grimm, R.E., Heggy, E., Clifford, S.M., Dinwiddie, C.L., McGinnis, R., Farrell, D., 2006. Absorption and scattering in ground-penetrating radar: Analysis of the Bishop Tuff. J. Geophys. Res. E Planets. https://doi.org/10.1029/2005JE002619

Haeni, F.P., 1996. Use of Ground-Penetrating Radar and Continuous Seismic-Reflection Profiling on Surface-Water Bodies in Environmental and Engineering Studies. J. Environ. Eng. Geophys. https://doi.org/10.4133/jeeg1.1.27

Halmai, Á., Gradwohl-Valkay, A., Czigány, S., Ficsor, J., Liptay, Z.Á., Kiss, K., Lóczy, D., Pirkhoffer, E., 2020. Applicability of a recreational-grade interferometric sonar for the bathymetric survey and monitoring of the Drava River. ISPRS Int. J. Geo-Information. https://doi.org/10.3390/ijgi9030149

Hayashi, M., 2004. Temperature-electrical conductivity relation of water for environmental monitoring and geophysical data inversion. Environ. Monit. Assess. https://doi.org/10.1023/B:EMAS.0000031719.83065.68

Helminen, J., Linnansaari, T., Bruce, M., Dolson-Edge, R., Curry, R.A., 2019. Accuracy and Precision of Low-Cost Echosounder and Automated Data Processing Software for Habitat Mapping in a Large River. Diversity. https://doi.org/10.3390/d11070116

Hilldale, R.C., Raff, D., 2008. Assessing the ability of airborne LiDAR to map river bathymetry. Earth Surf. Process. Landforms 33, 773-783. https://doi.org/10.1002/esp.1575

Huisman, J.A., Hubbard, S.S., Redman, J.D., Annan, A.P., 2003. Measuring Soil Water Content with Ground Penetrating Radar: A Review. Vadose Zo. J. https://doi.org/10.2136/vzj2003.4760

Jagalingam, P., Akshaya, B.J., Hegde, A.V., 2015. Bathymetry mapping using landsat 8 satellite imagery, in: Procedia Engineering. pp. 560-566. https://doi.org/10.1016/j.proeng.2015.08.326

Jiang, S., Georgakopoulos, S., 2011. Electromagnetic Wave Propagation into Fresh Water. J. Electromagn. Anal. Appl. https://doi.org/10.4236/jemaa.2011.37042

Kidmose, J., Engesgaard, P., Nilsson, B., Laier, T., Looms, M.C., 2011. Spatial Distribution of Seepage at a Flow-Through Lake: Lake Hampen, Western Denmark. Vadose Zo. J. https://doi.org/10.2136/vzj2010.0017

Kidmose, J., Nilsson, B., Engesgaard, P., Frandsen, M., Karan, S., Landkildehus, F., Søndergaard, M., Jeppesen, E., 2013. Focused groundwater discharge of phosphorus to a eutrophic seepage lake (Lake Væng, Denmark): Implications for lake ecological state and restoration. Hydrogeol. J.

https://doi.org/10.1007/s10040-013-1043-7

Kinzel, P.J., Legleiter, C.J., 2019. sUAS-based remote sensing of river discharge using thermal particle image velocimetry and bathymetric lidar. Remote Sens. https://doi.org/10.3390/rs11192317

Kinzel, P.J., Legleiter, C.J., Nelson, J.M., 2013. Mapping River Bathymetry With a Small Footprint Green LiDAR: Applications and Challenges. J. Am. Water Resour. Assoc. https://doi.org/10.1111/jawr.12008

Kinzel, P.J., Wright, C.W., Nelson, J.M., Burman, A.R., 2007. Evaluation of an Experimental LiDAR for Surveying a Shallow, Braided, Sand-Bedded River. J. Hydraul. Eng. 133, 838-842. https://doi.org/10.1061/(ASCE)0733-9429(2007)133:7(838)

Kovacs, A., 1979. Remote detection of water under ice-covered lakes on the north slope of Alaska. Arctic. https://doi.org/10.14430/arctic2672

Lachhab, A., Booterbaugh, A., Beren, M., 2015. Bathymetry and Sediment Accumulation of Walker Lake, PA Using Two GPR Antennas in a New Integrated Method. J. Environ. Eng. Geophys. https://doi.org/10.2113/JEEG20.3.245

Lague, D., Feldmann, B., 2020. Topo-bathymetric airborne LiDAR for fluvial-geomorphology analysis, in: Developments in Earth Surface Processes. https://doi.org/10.1016/B978-0-444-64177-9.00002-3

Page $14 / 23$ 
Lambot, S., Antoine, M., van den Bosch, I., Slob, E.C., Vanclooster, M., 2004. Electromagnetic Inversion of GPR Signals and Subsequent Hydrodynamic Inversion to Estimate Effective Vadose Zone Hydraulic Properties. Vadose Zo. J. https://doi.org/10.2113/3.4.1072

Lane, S.N., Tayefi, V., Reid, S.C., Yu, D., Hardy, R.J., 2007. Interactions between sediment delivery, channel change, climate change and flood risk in a temperate upland environment. Earth Surf. Process. Landforms. https://doi.org/10.1002/esp.1404

Lane, S.N., Widdison, P.E., Thomas, R.E., Ashworth, P.J., Best, J.L., Lunt, I.A., Sambrook Smith, G.H., Simpson, C.J., 2010. Quantification of braided river channel change using archival digital image analysis. Earth Surf. Process. Landforms 35, 971-985. https://doi.org/10.1002/esp.2015

Lapazaran, J.J., Otero, J., Martín-Español, A., Navarro, F.J., 2016. On the errors involved in ice-thickness estimates I: Ground-penetrating radar measurement errors. J. Glaciol. https://doi.org/10.1017/jog.2016.93

Leckebusch, J., Peikert, R., 2001. Investigating the true resolution and three-dimensional capabilities of ground-penetrating radar data in archaeological surveys: Measurements in a sand box. Archaeol. Prospect. https://doi.org/10.1002/1099-0763(200103)8:1<29::AID-ARP154>3.0.C0;2-T

Legleiter, C.J., 2012. Remote measurement of river morphology via fusion of LiDAR topography and spectrally based bathymetry. Earth Surf. Process. Landforms 37, 499-518. https://doi.org/10.1002/esp.2262

Legleiter, C.J., Roberts, D.A., Lawrence, R.L., 2009. Spectrally based remote sensing of river bathymetry. Earth Surf. Process. Landforms 34, $1039-1059$. https://doi.org/10.1002/esp.1787

Lejot, J., Delacourt, C., Piégay, H., Fournier, T., Trémélo, M.-L., Allemand, P., 2007. Very high spatial resolution imagery for channel bathymetry and topography from an unmanned mapping controlled platform. Earth Surf. Process. Landforms 32, 1705-1725. https://doi.org/10.1002/esp.1595

Leon, J.G., Calmant, S., Seyler, F., Bonnet, M.P., Cauhopé, M., Frappart, F., Filizola, N., Fraizy, P., 2006. Rating curves and estimation of average water depth at the upper Negro River based on satellite altimeter data and modeled discharges. J. Hydrol. https://doi.org/10.1016/j.jhydrol.2005.12.006

Leucci, G., Negri, S., 2006. Use of ground penetrating radar to map subsurface archaeological features in an urban area. J. Archaeol. Sci. https://doi.org/10.1016/j.jas.2005.09.006

Leyland, J., Hackney, C.R., Darby, S.E., Parsons, D.R., Best, J.L., Nicholas, A.P., Aalto, R., Lague, D., 2017. Extreme flood-driven fluvial bank erosion and sediment loads: direct process measurements using integrated Mobile Laser Scanning (MLS) and hydro-acoustic techniques, in: Earth Surface Processes and Landforms. https://doi.org/10.1002/esp.4078

Liu, H., Takahashi, K., Sato, M., 2014. Measurement of dielectric permittivity and thickness of snow and ice on a brackish lagoon using GPR. IEEE J. Sel. Top. Appl. Earth Obs. Remote Sens. https://doi.org/10.1109/JSTARS.2013.2266792

Liu, H., Xie, X., Sato, M., 2013. New ground penetrating radar system for quantitative characterization of snow and sea ice, in: IET Conference Publications. https://doi.org/10.1049/cp.2013.0122

Lyons, M., Phinn, S., Roelfsema, C., 2011. Integrating Quickbird multi-spectral satellite and field data: Mapping bathymetry, seagrass cover, seagrass species and change in Moreton Bay, Australia in 2004 and 2007. Remote Sens. 3, 42-64. https://doi.org/10.3390/rs3010042

Lyzenga, D.R., 1981. Remote sensing of bottom reflectance and water attenuation parameters in shallow water using aircraft and Landsat data. Int. J. Remote Sens. 2, 71-82. https://doi.org/10.1080/01431168108948342

Lyzenga, D.R., 1978. Passive remote sensing techniques for mapping water depth and bottom features. Appl. Opt. 17, 379-383.

https://doi.org/10.1364/A0.17.000379

Ma, Y., Xu, N., Liu, Z., Yang, B., Yang, F., Wang, X.H., Li, S., 2020. Satellite-derived bathymetry using the ICESat-2 lidar and Sentinel-2 imagery datasets. Remote Sens. Environ. https://doi.org/10.1016/j.rse.2020.112047

Machguth, H., Eisen, O., Paul, F., Hoelzle, M., 2006. Strong spatial variability of snow accumulation observed with helicopter-borne GPR on two adjacent Alpine glaciers. Geophys. Res. Lett. https://doi.org/10.1029/2006GL026576

Malmberg, C.G., Maryott, A.A., 1956. Dielectric constant of water from 0 to 100 C. J. Res. Natl. Bur. Stand. (1934). https://doi.org/10.6028/jres.056.001

Mandlburger, G., Pfennigbauer, M., Wieser, M., Riegl, U., Pfeifer, N., 2016. Evaluation Of A Novel Uav-Borne Topo-Bathymetric Laser Profiler. ISPRS - Int. Arch. Photogramm. Remote Sens. Spat. Inf. Sci. XLI-B1, 933-939. https://doi.org/10.5194/isprs-archives-XLI-B1-933-2016

Marcus, W.A., Legleiter, C.J., Aspinall, R.J., Boardman, J.W., Crabtree, R.L., 2003. High spatial resolution hyperspectral mapping of in-stream habitats, depths, and woody debris in mountain streams. Geomorphology 55, 363-380. https://doi.org/10.1016/S0169-555X(03)00150-8

Marcus, W.A., Marston, R.A., Colvard, C.R., Gray, R.D., 2002. Mapping the spatial and temporal distributions of woody debris in streams of the Greater Yellowstone Ecosystem, USA. Geomorphology. https://doi.org/10.1016/S0169-555X(01)00181-7 
Mason, R., 2004. Evaluating a Radar-based, Non Contact Streamflow Measurement System in the San Joaquin River at Vernalis, California. US Geol. Surv. open file Rep.

Melcher, N.B., Costa, J.E., Haeni, F.P., Cheng, R.T., Thurman, E.M., Buursink, M., Spicer, K.R., Hayes, E., Plant, W.J., Keller, W.C., Hayes, K., 2002. River discharge measurements by using helicopter-mounted radar. Geophys. Res. Lett. https://doi.org/10.1029/2002gl015525

Merwade, V., 2009. Effect of spatial trends on interpolation of river bathymetry. J. Hydrol. https://doi.org/10.1016/j.jhydrol.2009.03.026

Merz, K., Maurer, H., Buchli, T., Horstmeyer, H., Green, A.G., Springman, S.M., 2015. Evaluation of ground-based and helicopter ground-penetrating radar data acquired across an alpine rock glacier. Permafr. Periglac. Process. https://doi.org/10.1002/ppp.1836

Moorman, B.J., Michel, F.A., 1997. Bathymetric mapping and sub-bottom profiling through lake ice with ground-penetrating radar. J. Paleolimnol. https://doi.org/10.1023/A:1007920816271

Moramarco, T., Barbetta, S., Bjerklie, D.M., Fulton, J.W., Tarpanelli, A., 2019. River Bathymetry Estimate and Discharge Assessment from Remote Sensing. Water Resour. Res. https://doi.org/10.1029/2018WR024220

Muzirafuti, A., Barreca, G., Crupi, A., Faina, G., Paltrinieri, D., Lanza, S., Randazzo, G., 2020. The contribution of multispectral satellite image to shallowwater bathymetry mapping on the Coast of Misano Adriatico, Italy. J. Mar. Sci. Eng. https://doi.org/10.3390/jmse8020126

Nobes, D.C., Hammond, K.A., Bassett, K.N., 2018. Effect of suspended sediments on ground penetrating radar imaging of riverbeds, in: 2018 17th International Conference on Ground Penetrating Radar, GPR 2018. https://doi.org/10.1109/ICGPR.2018.8441671

Overstreet, B.T., Legleiter, C.J., 2017. Removing sun glint from optical remote sensing images of shallow rivers. Earth Surf. Process. Landforms $42,318-333$. https://doi.org/10.1002/esp.4063

Pan, Z., Glennie, C., Hartzell, P., Fernandez-Diaz, J.C., Legleiter, C., Overstreet, B., 2015. Performance assessment of high resolution airborne full waveform LiDAR for shallow river bathymetry. Remote Sens. https://doi.org/10.3390/rs70505133

Parrish, C.E., Magruder, L.A., Neuenschwander, A.L., Forfinski-Sarkozi, N., Alonzo, M., Jasinski, M., 2019. Validation of ICESat-2 ATLAS bathymetry and analysis of ATLAS's bathymetric mapping performance. Remote Sens. https://doi.org/10.3390/rs11141634

Pérez-Gracia, V., González-Drigo, R., Di Capua, D., 2008. Horizontal resolution in a non-destructive shallow GPR survey: An experimental evaluation. NDT E Int. https://doi.org/10.1016/j.ndteint.2008.06.002

Rappaport, C., El-Shenawee, M., Zhan, H., 2003. Suppressing GPR Clutter from Randomly Rough Ground Surfaces to Enhance Nonmetallic Mine Detection. Subsurf. Sens. Technol. Appl. https://doi.org/10.1023/A:1026352615393

Reynolds, J.M., 1997. An introduction to applied and environmental geophysics, An introduction to applied and environmental geophysics. https://doi.org/10.1071/pvv2011n155other

Rossi, L., Mammi, I., Pelliccia, F., 2020. UAV-Derived Multispectral Bathymetry. Remote Sens. 12, 3897. https://doi.org/10.3390/rs12233897

Rutishauser, A., Maurer, H., Bauder, A., 2016. Helicopter-borne ground-penetrating radar investigations on temperate alpine glaciers: A comparison of different systems and their abilities for bedrock mapping. Geophysics. https://doi.org/10.1190/GEO2015-0144.1

Sabol, B., 2002. Hydrographic surveying in dense Aquatic Vegetation. Digital signal processing for improved bottom tracking. Hydro Int.

Saintenoy, A., Friedt, J.M., Booth, A.D., Tolle, F., Bernard, E., Laffly, D., Marlin, C., Griselin, M., 2013. Deriving ice thickness, glacier volume and bedrock morphology of Austre Lovénbreen (Svalbard) using GPR. Near Surf. Geophys. https://doi.org/10.3997/1873-0604.2012040

Sambuelli, L., Bava, S., 2012. Case study: A GPR survey on a morainic lake in northern Italy for bathymetry, water volume and sediment characterization. J. Appl. Geophys. https://doi.org/10.1016/j.jappgeo.2011.09.016

Sambuelli, L., Calzoni, C., Pesenti, M., 2009. Waterborne GPR survey for estimating bottom-sediment variability: A survey on the Po River, Turin, Italy. GEOPHYSICS. https://doi.org/10.1190/1.3119262

Schwamborn, G.J., Dix, J.K., Bull, J.M., Rachold, V., 2002. High-resolution seismic and ground penetrating radar-geophysical profiling of a thermokarst lake in the western Lena Delta, northern Siberia. Permafr. Periglac. Process. https://doi.org/10.1002/ppp.430

Shean, D.E., Marchant, D.R., 2010. Seismic and GPR surveys of Mullins Glacier, mcmurdo dry valleys, Antarctica: Ice thickness, internal structure and implications for surface ridge formation. J. Glaciol. https://doi.org/10.3189/002214310791190901

Slocum, R.K., Parrish, C.E., Simpson, C.H., 2020. Combined geometric-radiometric and neural network approach to shallow bathymetric mapping with UAS imagery. ISPRS J. Photogramm. Remote Sens. https://doi.org/10.1016/j.isprsjprs.2020.09.002

Specht, C., Lewicka, O., Specht, M., Dabrowski, P., Burdziakowski, P., 2020. Methodology for carrying out measurements of the tombolo geomorphic landform using unmanned aerial and surface vehicles near Sopot Pier, Poland. J. Mar. Sci. Eng. https://doi.org/10.3390/JMSE8060384

Page 16/23 
Spicer, K.R., Costa, J.E., Placzek, G., 1997. Measuring flood discharge in unstable stream channels using ground-penetrating radar. Geology $25,423-426$. https://doi.org/10.1130/0091-7613(1997)025<0423:MFDIUS>2.3.CO

Starek, M.J., Giessel, J., 2017. Fusion of uas-based structure-from-motion and optical inversion for seamless topo-bathymetric mapping, in: International Geoscience and Remote Sensing Symposium (IGARSS). https://doi.org/10.1109/IGARSS.2017.8127629

Stateczny, A., Błaszczak-Bak, W., Sobieraj-Złobińska, A., Motyl, W., Wisniewska, M., 2019. Methodology for processing of 3D multibeam sonar big data for comparative navigation. Remote Sens. https://doi.org/10.3390/rs11192245

Stover, S.C., Montgomery, D.R., 2001. Channel change and flooding, Skokomish River, Washington. J. Hydrol. https://doi.org/10.1016/S0022-1694(00)00421-2

Stumpf, R.P., Holderied, K., Sinclair, M., 2003. Determination of water depth with high-resolution satellite imagery over variable bottom types. Limnol. Oceanogr. 48, 547-556. https://doi.org/10.4319/lo.2003.48.1_part_2.0547

Swain, A.K., 2018. Bathymetry of Schirmacher lakes as a tool for geomorphological evolution studies, in: Geological Society Special Publication. https://doi.org/10.1144/SP461.13

Takasu, T., Yasuda, A., 2009. Development of the low-cost RTK-GPS receiver with an open source program package RTKLIB. Int. Symp. GPS/GNSS.

Tamminga, a., Hugenholtz, C., Eaton, B., Lapointe, M., 2014. Hyperspatial Remote Sensing of Channel Reach Morphology and Hydraulic Fish Habitat Using an Unmanned Aerial Vehicle (Uav): a First Assessment in the Context of River Research and Management. River Res. Appl. 31, $379-391$.

https://doi.org/10.1002/rra.2743

Utsi, E., 2004. Ground-penetrating radar time-slices from North Ballachulish Moss. Archaeol. Prospect. https://doi.org/10.1002/arp.223

Wei, J., Wang, M., Lee, Z., Briceño, H.O., Yu, X., Jiang, L., Garcia, R., Wang, J., Luis, K., 2020. Shallow water bathymetry with multi-spectral satellite ocean color sensors: Leveraging temporal variation in image data. Remote Sens. Environ. https://doi.org/10.1016/j.rse.2020.112035

Westaway, R.M., Lane, S.N., Hicks, D.M., 2001. Remote sensing of clear-water, shallow, gravel-bed rivers using digital photogrammetry. Photogramm. Eng. Remote Sensing 67, 1271-1281.

Winterbottom, S.J., Gilvear, D.J., 1997. Quantification of channel bed morphology in gravel-bed rivers using airborne multispectral imagery and aerial photography. Regul. Rivers-Research Manag. 13, 489-499. https://doi.org/10.1002/(SICI)1099-1646(199711/12)13:6<489::AID-RRR471>3.0.CO;2-X

Woodget, A.S., Carbonneau, P.E., Visser, F., Maddock, I.P., 2015. Quantifying submerged fluvial topography using hyperspatial resolution UAS imagery and structure from motion photogrammetry. Earth Surf. Process. Landforms 40, 47-64. https://doi.org/10.1002/esp.3613

Yao, J., Zhang, Q., Ye, X., Zhang, D., Bai, P., 2018. Quantifying the impact of bathymetric changes on the hydrological regimes in a large floodplain lake: Poyang Lake. J. Hydrol. https://doi.org/10.1016/j.jhydrol.2018.04.035

Yoshikawa, K., Leuschen, C., Ikeda, A., Harada, K., Gogineni, P., Hoekstra, P., Hinzman, L., Sawada, Y., Matsuoka, N., 2006. Comparison of geophysical investigations for detection of massive ground ice (pingo ice). J. Geophys. Res. E Planets. https://doi.org/10.1029/2005JE002573

Young, S., Peschel, J., Penny, G., Thompson, S., Srinivasan, V., 2017. Robot-assisted measurement for hydrologic understanding in data sparse regions. Water (Switzerland). https://doi.org/10.3390/w9070494

\section{Figures}



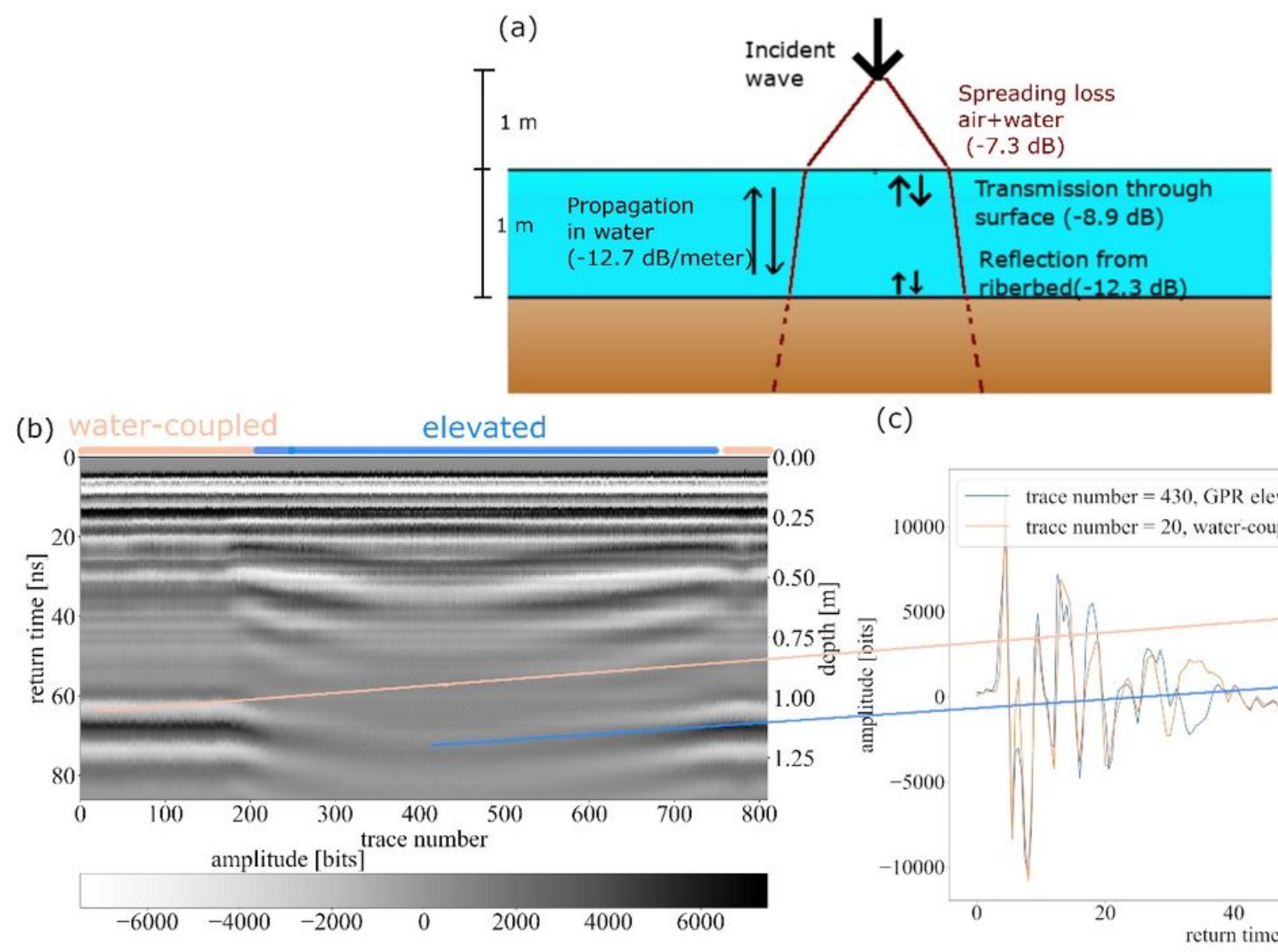

(c)

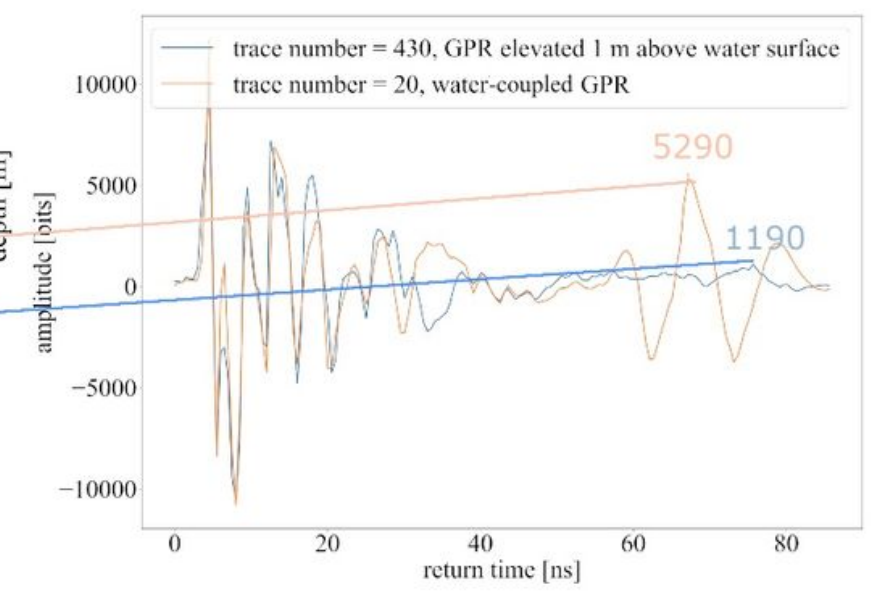

\section{Figure 1}

(a) different loss components for GPR propagation through air, through water and reflection from the riverbed; (b) radargram showing the returns from the lakebed (approx. 1 meter water depth) acquired by a GPR antenna ( $80 \mathrm{MHz}$ ) water-coupled (trace number between 0 to 180 and after 780) and slowly elevated above the water surface (e.g. at trace 430 antenna was elevated approx. $1 \mathrm{~m}$ above the water surface). (c) comparison of the lakebed return electric fieldstrength detected from water-coupled (trace 20) and elevated (trace 430) GPR antenna: the electric field-strength of the lakebed return is approx. 5290 bits for water-coupled, whilst only 1190 for the elevated antenna.

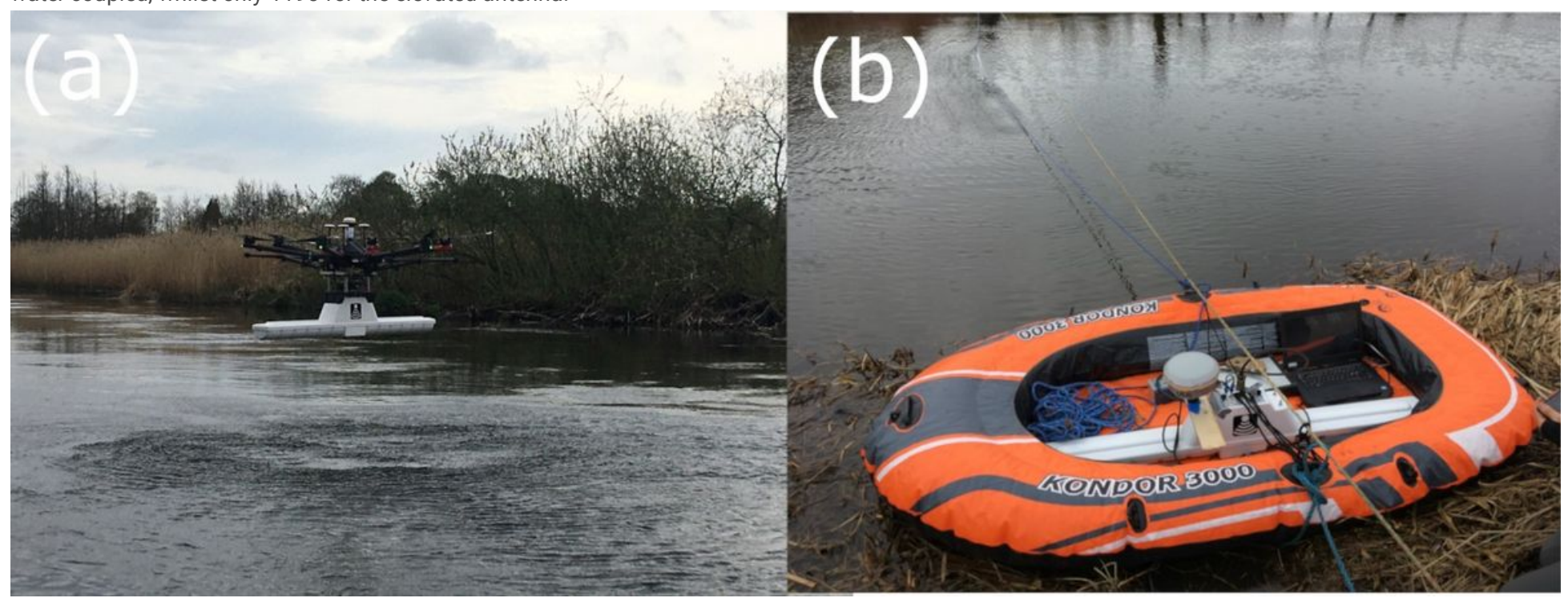

\section{Figure 2}

(a) drone-borne and (b) water-coupled deployment of GPR antenna Gekko-80. 


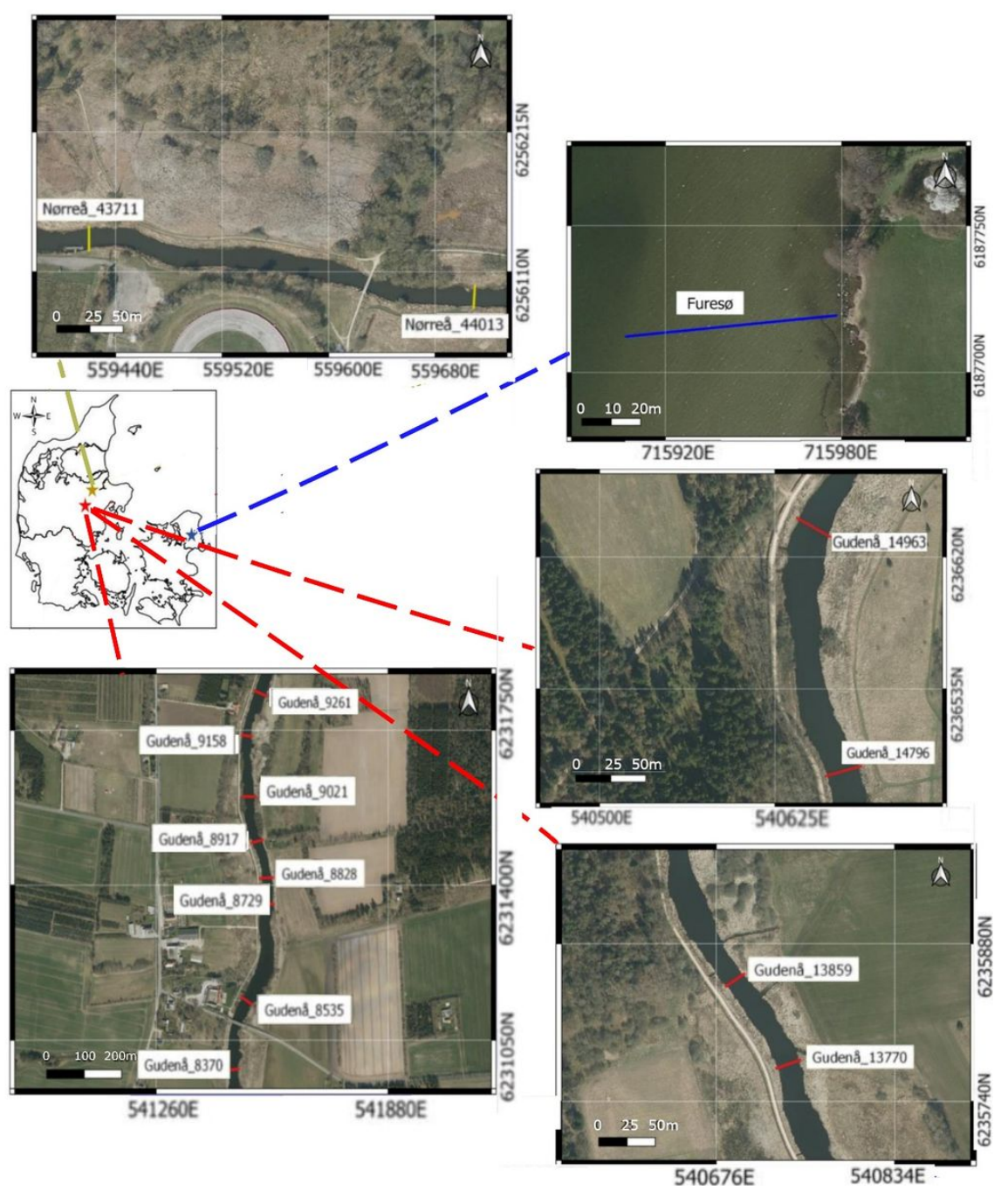

Figure 3

site overview map (coordinates in ETRS89-UTM32). The maps show the river cross-sections that were surveyed in Guden $\AA$, Nørreå, and the profile in Fures $\varnothing$ lake. 


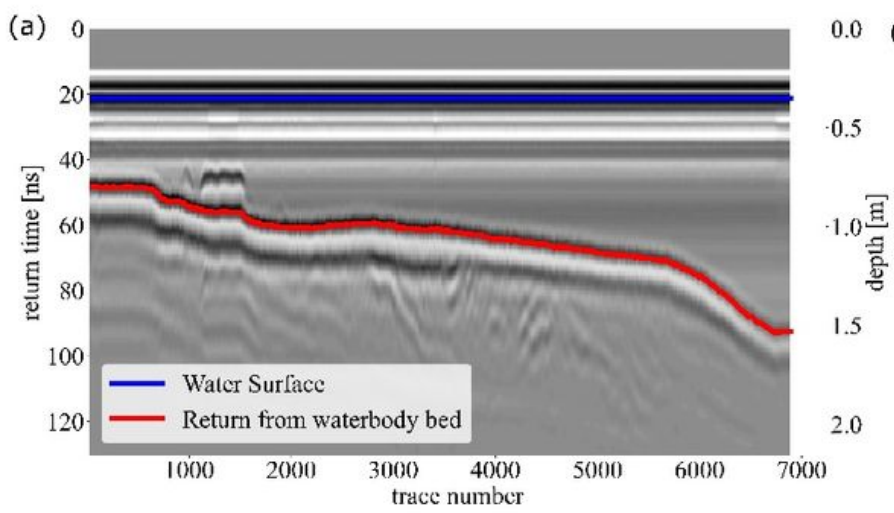

amplitude [bits]

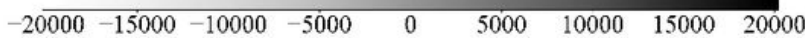

(c)

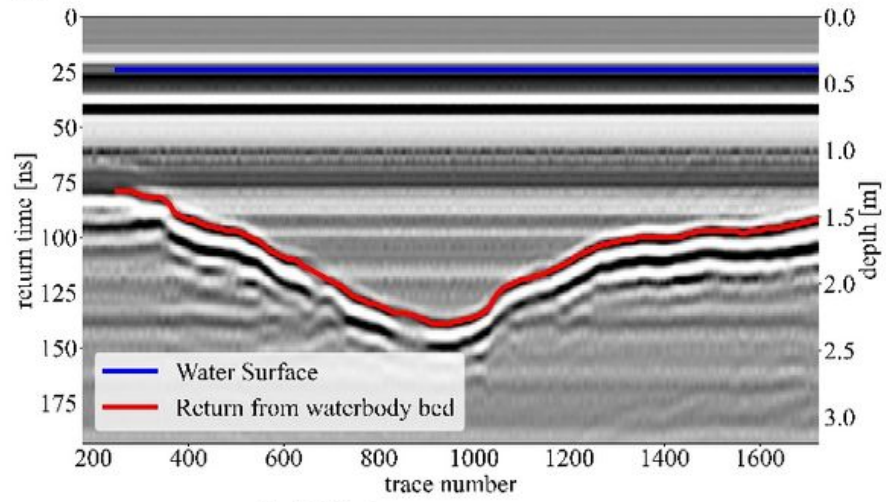

amplitude [bits]

$\begin{array}{lllllll}-30000 & -20000 & -10000 & 0 & 10000 & 20000 & 30000\end{array}$

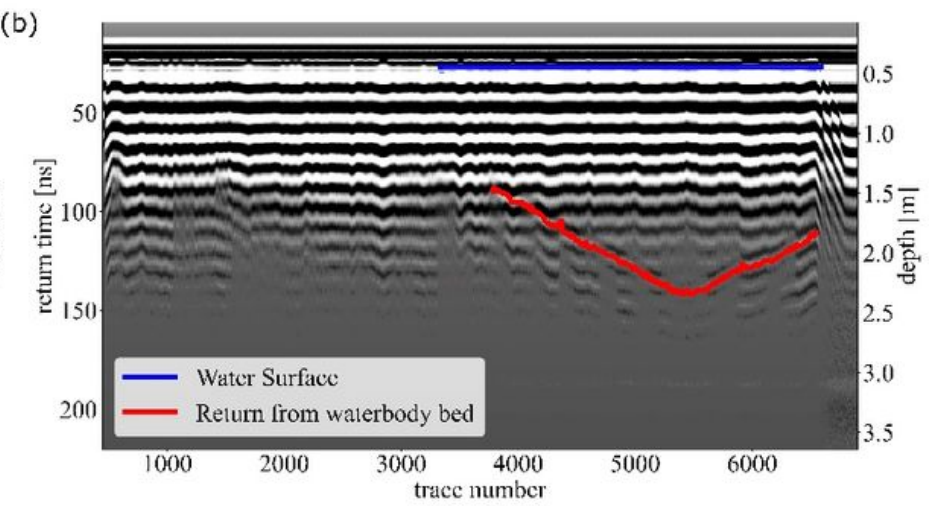

amplitude [bits]

\begin{tabular}{|lllllll|}
\hline-30000 & -20000 & -10000 & 0 & 10000 & 20000 & 30000
\end{tabular}

(d)

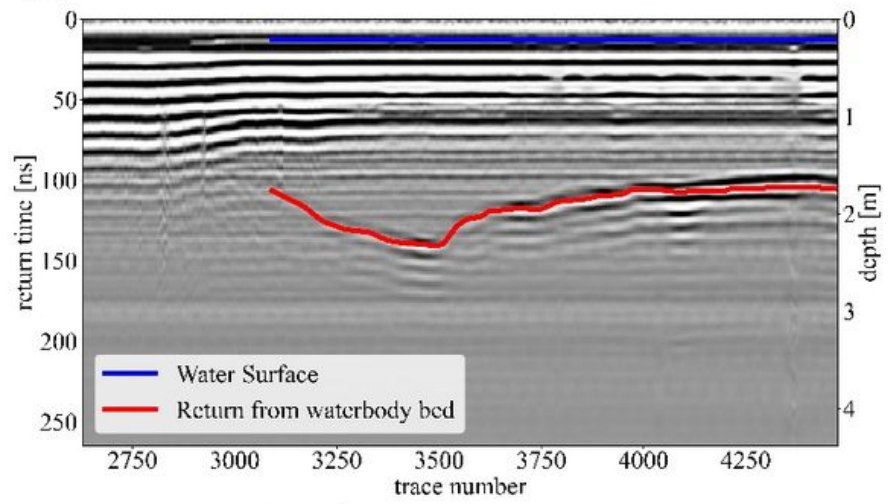

amplitude [bits]

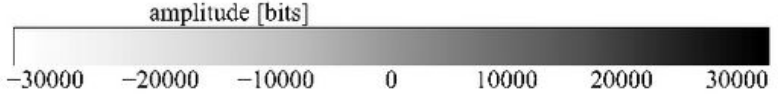

\section{Figure 4}

Fures $\varnothing$ radargram is shown in (a) water-coupled and (b) drone-borne. Guden_13770 is shown in (c) water-coupled and (d) drone-borne. Color lines indicated interpreted water surface and bottom returns 
(a)

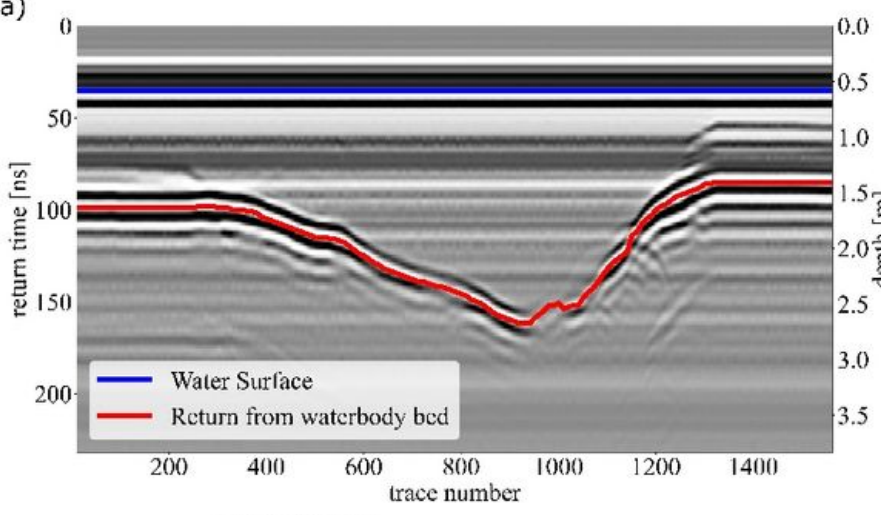

amplitude [bits]

$\begin{array}{lllllll}-30000 & -20000 & -10000 & 0 & 10000 & 20000 & 30000\end{array}$

(c)

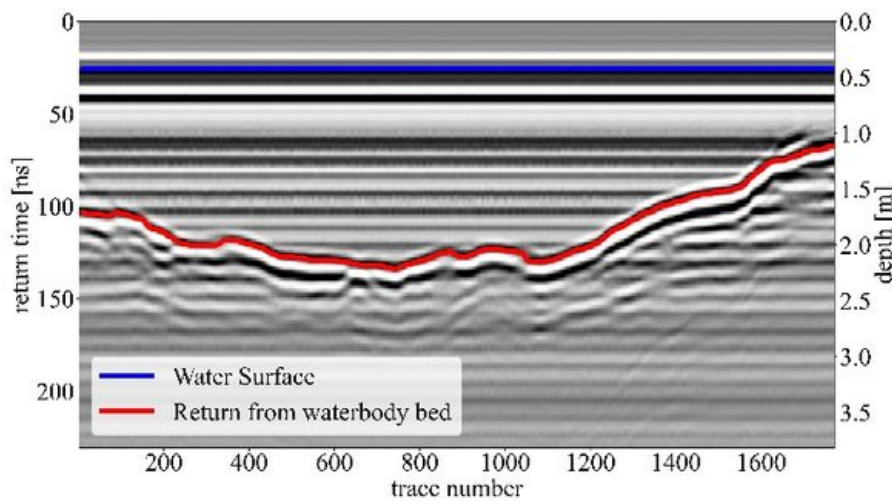

amplitude [bits]

\begin{tabular}{lllllll}
\hline-30000 & -20000 & -10000 & 0 & 10000 & 20000 & 30000
\end{tabular}

(b)

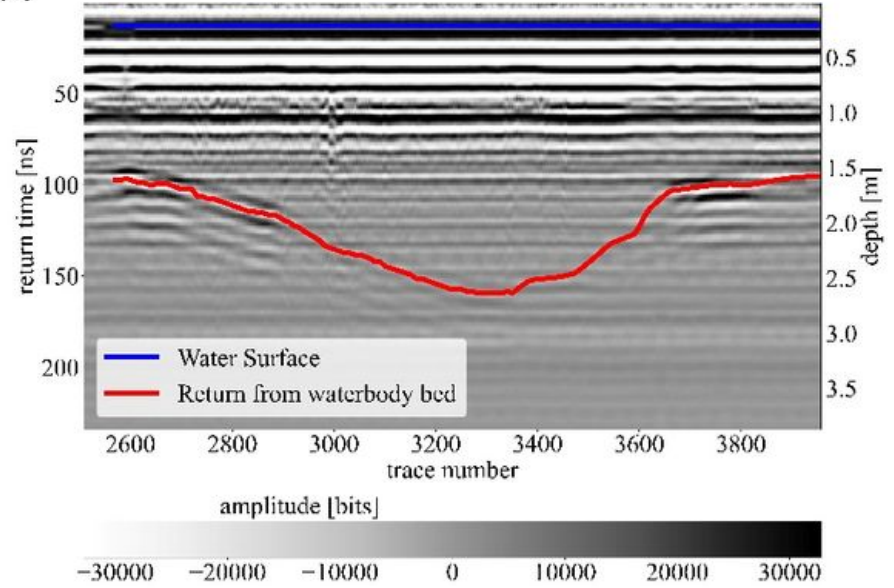

(d)

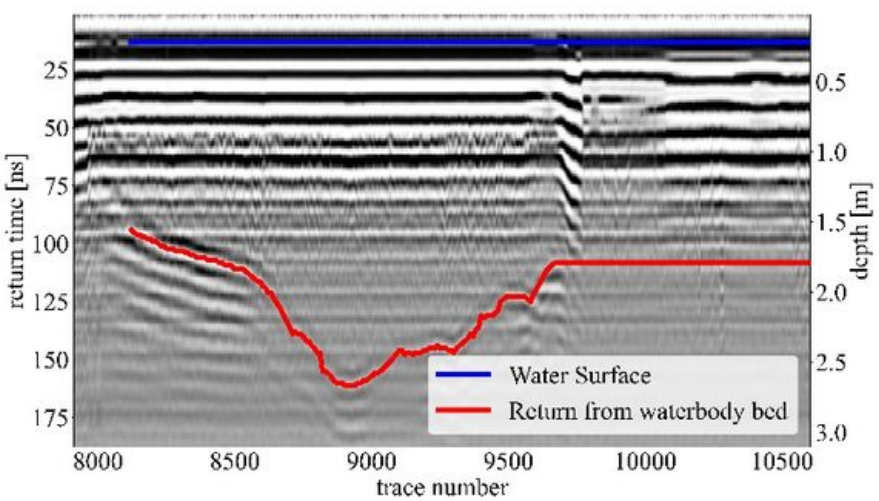

anıplitude [bits]

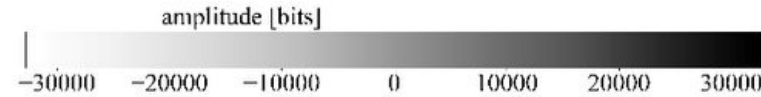

\section{Figure 5}

Guden_13859 radargram is shown in (a) water-coupled and (b) drone-borne. Guden 9158 is shown in (c) water-coupled and (d) drone-borne. Color lines indicated interpreted water surface and bottom returns. 
(a)

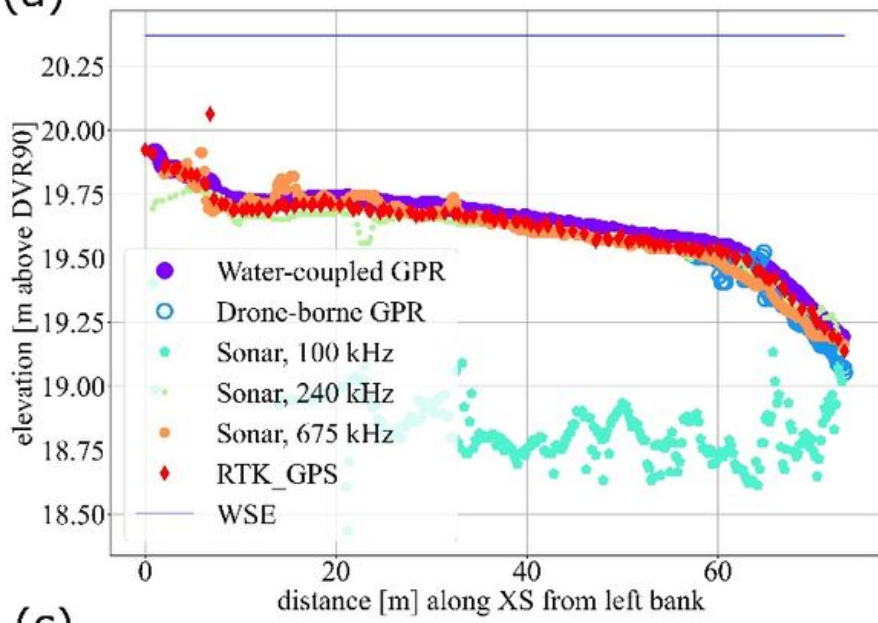

(c)

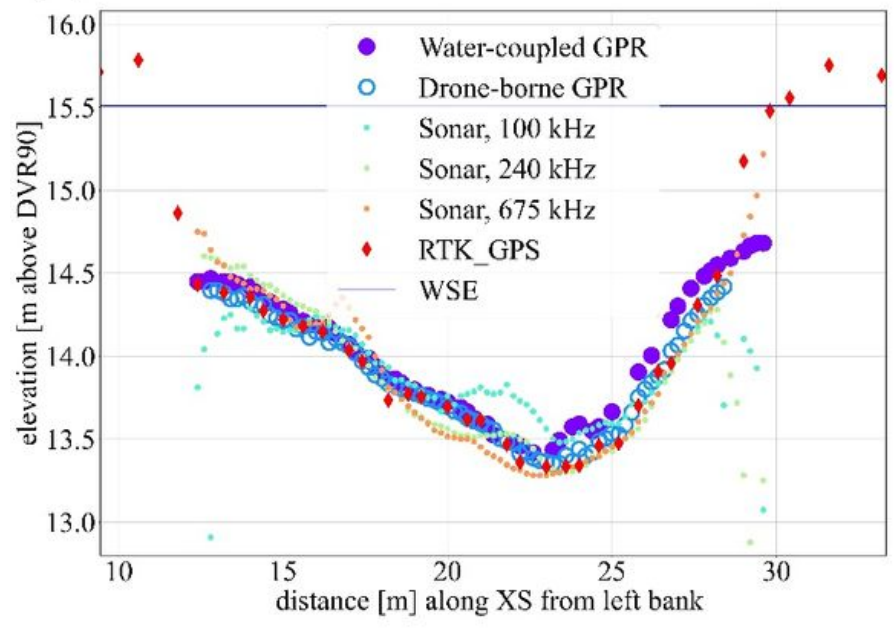

(b)

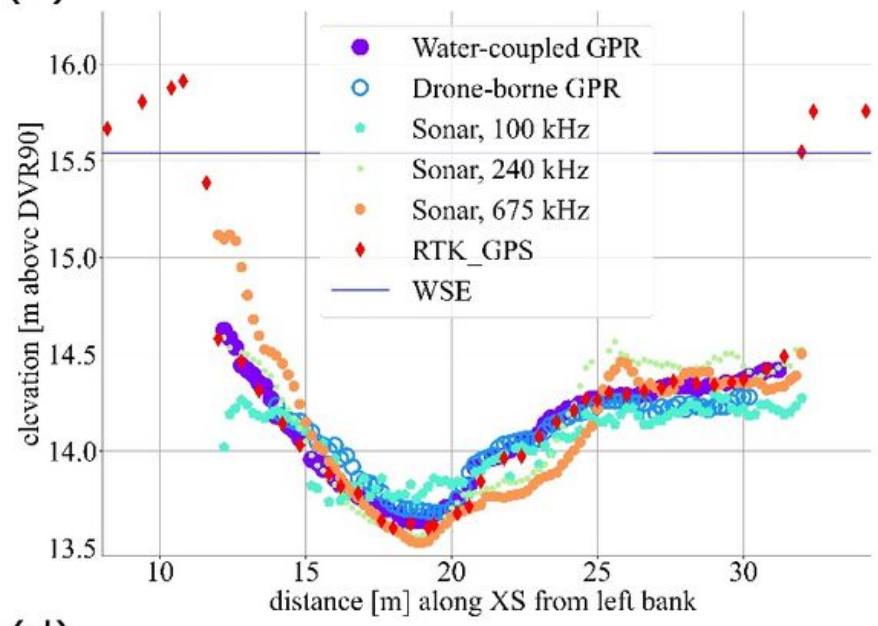

(d)

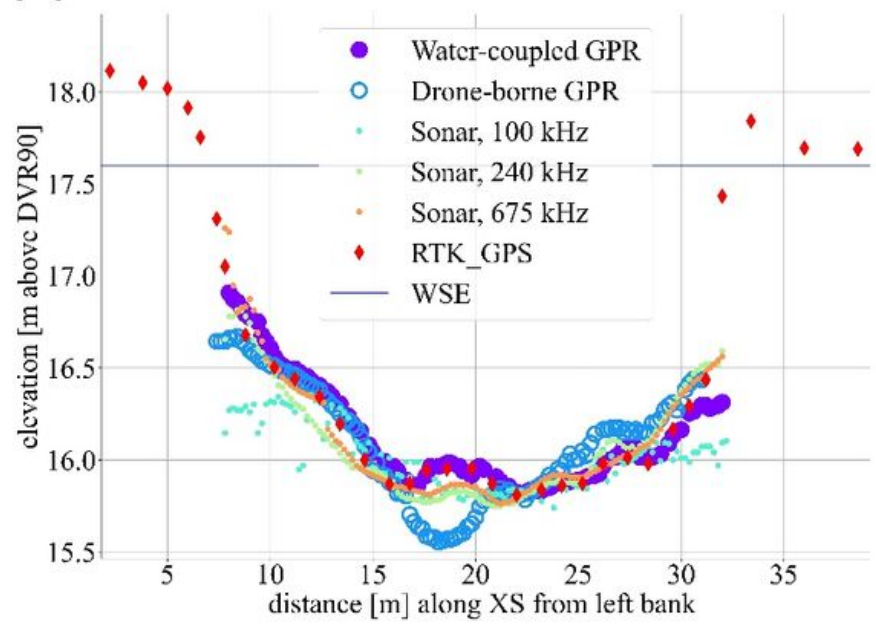

Figure 6

plots comparing the bathymetric measurements taken with RTK-GNSS, sonar (three different frequencies) and GPR. WSE, as measured by the RTK-GNSS, is plotted as a flat blue line. Sites: (a) is Fures $\varnothing$ (b) Guden_13770 (c) Guden_13859 (d) Guden_9158. All elevations are relative to DVR90, which is the standard vertical reference system (geoid) used in Denmark.

(a)

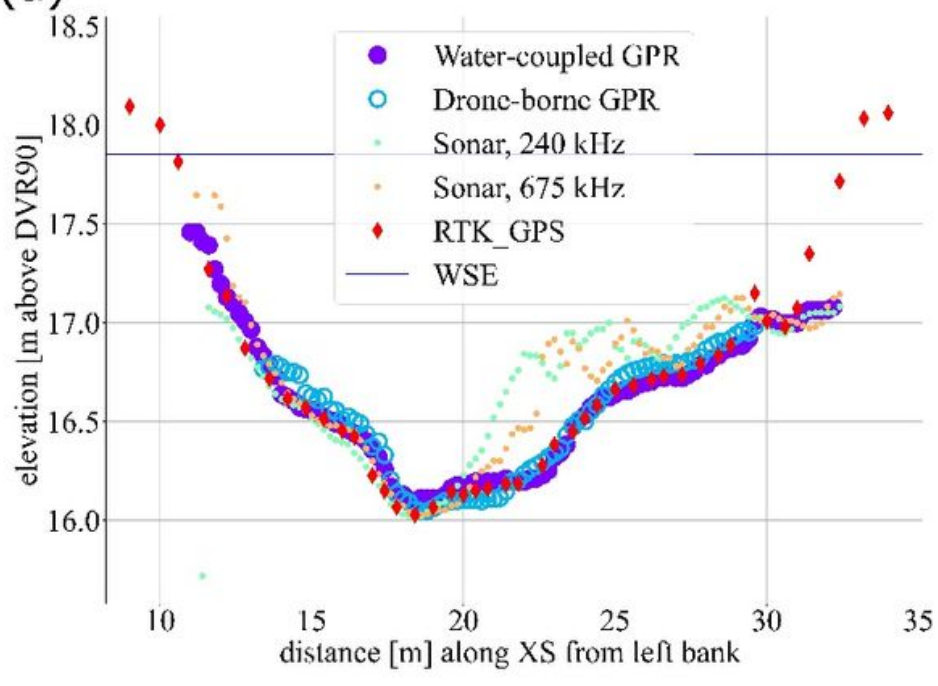

(b)

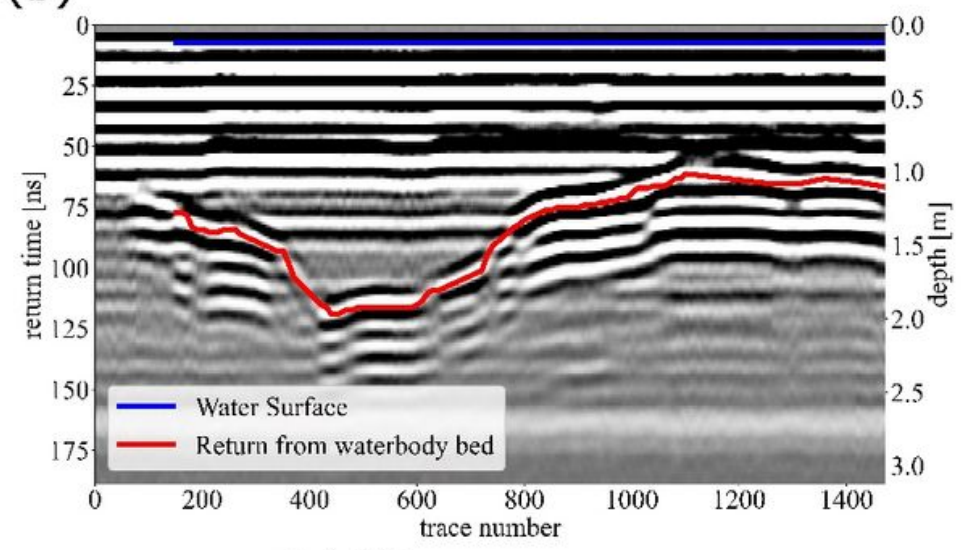
amplitude [bits]

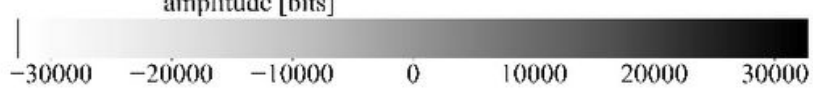

Figure 7

Guden_8370, which presented high aquatic vegetation density on the right side. (a) is the comparison between the bathymetric measurements of the different instruments (b) is the radargram of drone-borne GPR. 


\section{Supplementary Files}

This is a list of supplementary files associated with this preprint. Click to download.

- Supplementarymaterial.docx 